\title{
Company Interactions with Open Platforms: Case of Carrier Grade Linux
}

\author{
by \\ Jiang Yuan

\begin{abstract}
A thesis submitted to the Faculty of Graduate Studies and Research in partial fulfillment of the requirements for the degree of Master of Applied Science in Technology Innovation Management
\end{abstract} \\ Department of Systems and Computer Engineering \\ Carleton University \\ Ottawa, Canada, K1S 5B6 \\ August 2007
}

CCopyright 2007 Jiang Yuan 


$\begin{array}{ll}\begin{array}{l}\text { Library and } \\ \text { Archives Canada }\end{array} & \begin{array}{l}\text { Bibliothèque et } \\ \text { Archives Canada }\end{array} \\ \begin{array}{l}\text { Published Heritage } \\ \text { Branch }\end{array} & \begin{array}{l}\text { Direction du } \\ \text { Patrimoine de l'édition }\end{array} \\ \begin{array}{l}\text { 395 Wellington Street } \\ \text { Ottawa ON K1A ON4 }\end{array} & \begin{array}{l}\text { 395, rue Wellington } \\ \text { Ottawa ON K1A ON4 } \\ \text { Canada }\end{array}\end{array}$

Your file Votre référence ISBN: 978-0-494-33677-9 Our file Notre référence ISBN: 978-0-494-33677-9

NOTICE:

The author has granted a nonexclusive license allowing Library and Archives Canada to reproduce, publish, archive, preserve, conserve, communicate to the public by telecommunication or on the Internet, loan, distribute and sell theses worldwide, for commercial or noncommercial purposes, in microform, paper, electronic and/or any other formats.

The author retains copyright ownership and moral rights in this thesis. Neither the thesis nor substantial extracts from it may be printed or otherwise reproduced without the author's permission.
AVIS:

L'auteur a accordé une licence non exclusive permettant à la Bibliothèque et Archives Canada de reproduire, publier, archiver, sauvegarder, conserver, transmettre au public par télécommunication ou par l'Internet, prêter, distribuer et vendre des thèses partout dans le monde, à des fins commerciales ou autres, sur support microforme, papier, électronique et/ou autres formats.

L'auteur conserve la propriété du droit d'auteur et des droits moraux qui protège cette thèse. $\mathrm{Ni}$ la thèse ni des extraits substantiels de celle-ci ne doivent être imprimés ou autrement reproduits sans son autorisation.
In compliance with the Canadian

Privacy Act some supporting forms may have been removed from this thesis.

While these forms may be included in the document page count, their removal does not represent any loss of content from the thesis.
Conformément à la loi canadienne sur la protection de la vie privée, quelques formulaires secondaires ont été enlevés de cette thèse.

Bien que ces formulaires aient inclus dans la pagination, il n'y aura aucun contenu manquant.

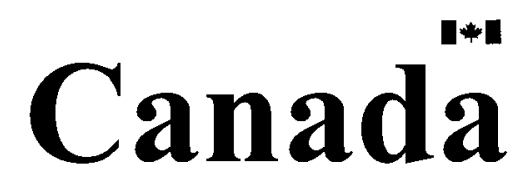




\section{ABSTRACT}

Carrier Grade Linux (CGL) stands at the center of the move to open architectures. This research answers three questions: (i) what motivates companies to incorporate CGL specifications into their products, (ii) how these companies create and appropriate value, and (iii) what roles these companies play in the ecosystem anchored around the CGL Working Group initiative. Two theoretical perspectives were used to examine publicly available information on nine companies. Research results suggest that companies incorporate CGL into their products to enter the telecommunications market and expand their market share. This research may help top management teams decide whether or not to incorporate open platforms into their products and what actions their companies can undertake to appropriate value created by open platform initiatives. Academics who study competitive environments may be interested in the approach used in this thesis to make sense of what we see occurring around the adoption of open platforms. 


\section{ACKNOWLEDGEMENTS}

I can still clearly remember the first TIM class when Professor Tony Bailetti brought in two copies of theses written by TIM graduates. Since then I have been pushed forward tirelessly by Tony to achieve the ultimate goal of TIM program - valuable TIM theses. For me, TIM program is a challenging journey as well as a rewarding experience.

Professor Tony Bailetti and John Callahan have been the greatest instructors and mentors. I believe that what I have learned in the TIM program, the knowledge, the methodology, and most importantly the attitude, will provide with me lifelong benefits.

I want to thank my family for always being there for me. Without their support, I could not make through one of the most important transitions in my life. My only regret is that I missed so many important moments in my daughter's life: her first steps, her first words, and many others. However, I believe she will be very proud of me when she grows up.

I also want to thank Professors David Coll, Michael Weiss, Steven Muegge, Stoyan Tanev and Dwight Deugo for the invaluable lessons and inspiring suggestions.

This thesis was developed as part of the Competing in Open Environments research program led by Tony Bailetti, Carleton University, and Peter Carbone, Nortel. The support received from Nortel for this research and the M.Eng. in Techonology Innovation Management program is gratefully acknowledged. 


\section{TABLE OF CONTENTS}

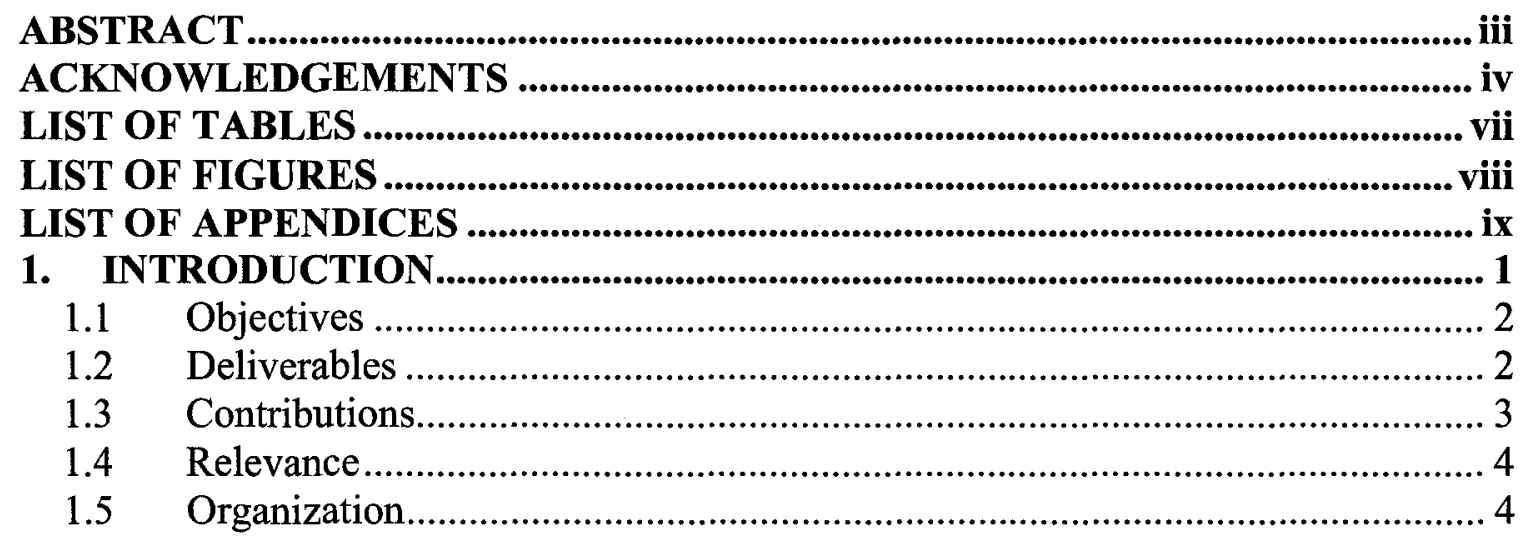

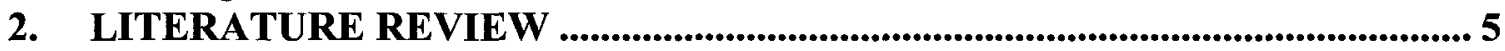

2.1 Companies' motivations for participating in open source projects ................... 5

$2.2 \quad$ Value creation and appropriation.............................................................. 7

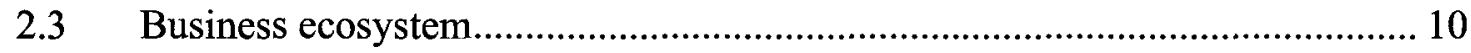

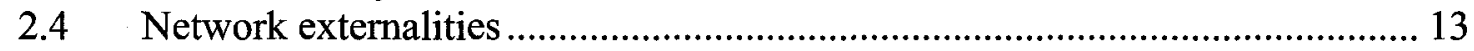

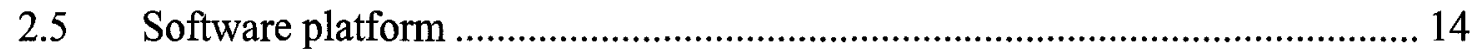

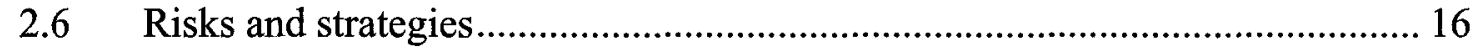

2.6.1 Risks of companies participating in open source projects ....................... 16

2.6.2 Open source business strategies........................................................... 17

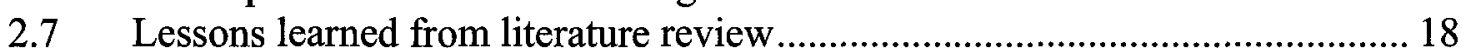

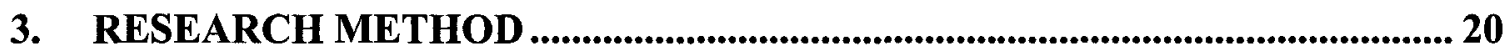

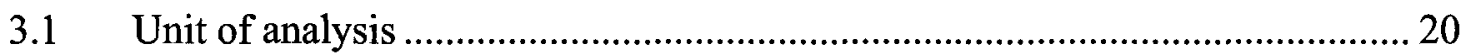

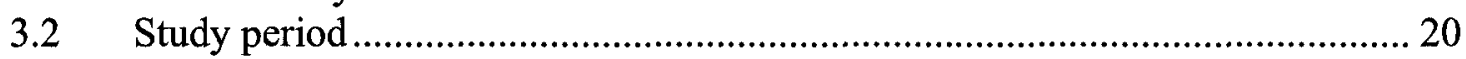

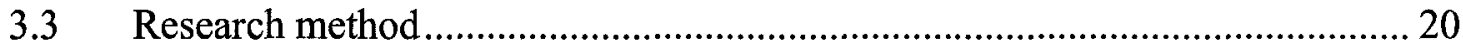

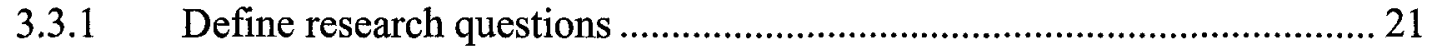

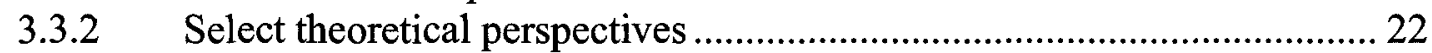

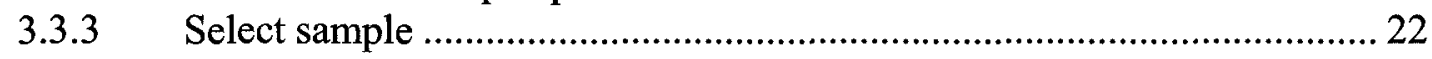

3.3.4 Define categories for companies' motivations, actions to create value, and

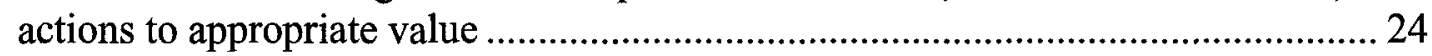

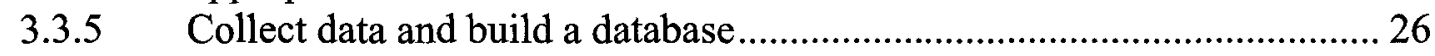

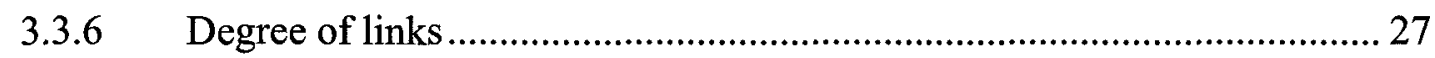

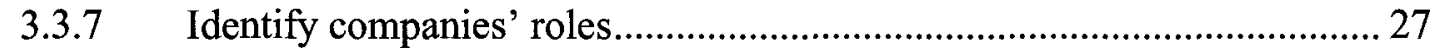

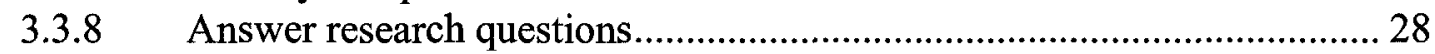

3.3.9 Generate insights for managers and academics .................................. 30

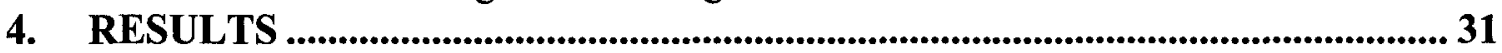

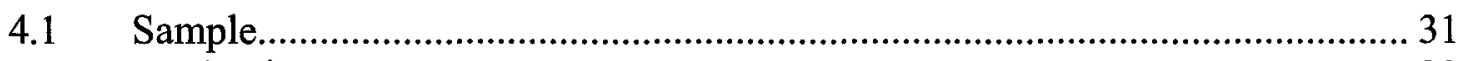

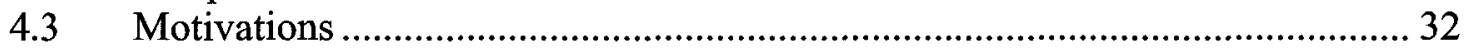

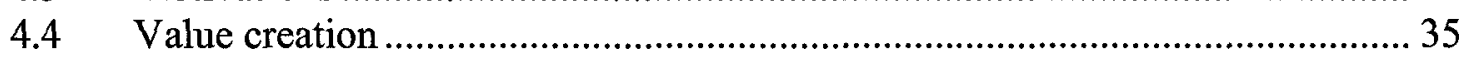

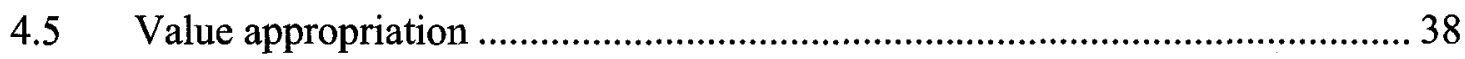

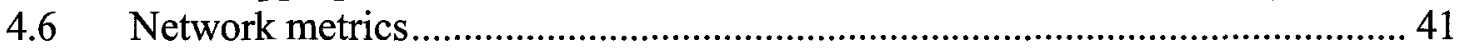

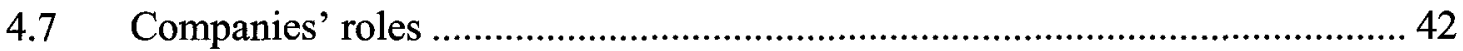

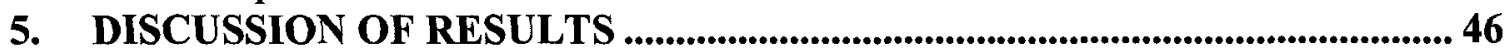

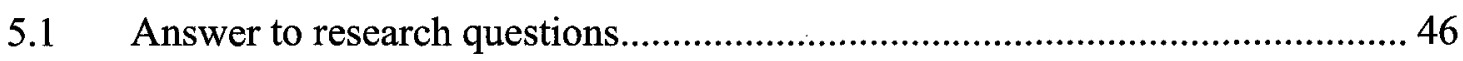


5.1.1 What motivates companies to incorporate CGL specifications into their market offers?

5.1.2 How do companies that incorporate CGL specifications into their products create and appropriate value? ......................................................................... 47

5.1.3 What roles do specific companies play in the business ecosystem anchored around the CGL Working Group initiative? ........................................................ 48

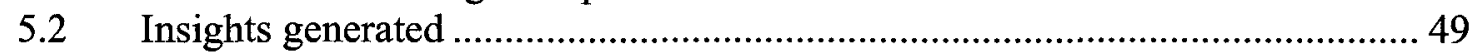

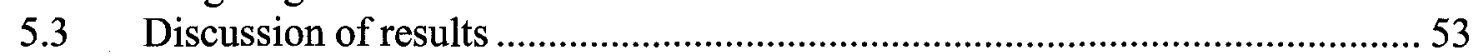

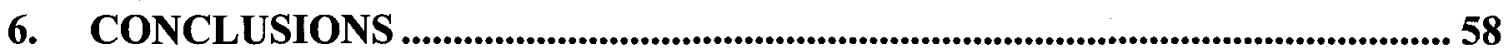

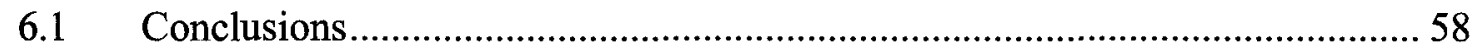

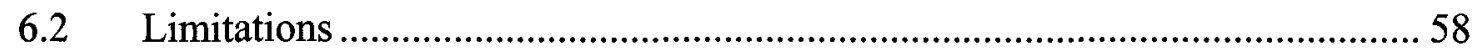

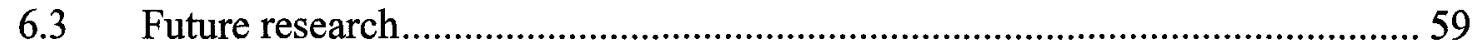

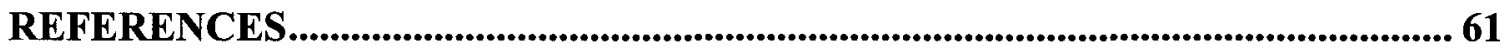




\section{LIST OF TABLES}

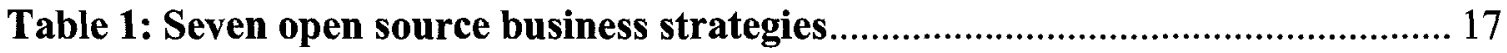

Table 2: Rationale for selecting theoretical perspectives ....................................... 22

Table 3: Motivations for companies to incorporate CGL into their market offers.. 34

Table 4: Actions carried out to create value from CGL initiative ............................ 37

Table 5: Actions carried out to appropriate value.................................................... 39

Table 6: Degree of links for companies in the sample ........................................... 41

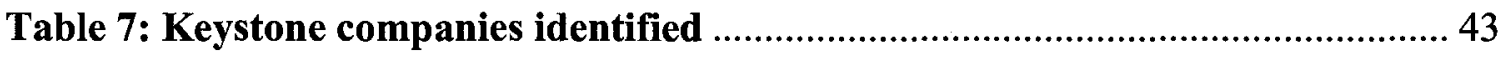

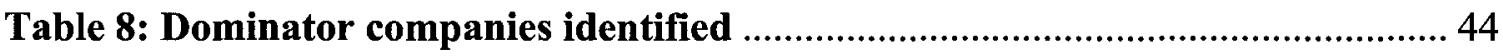

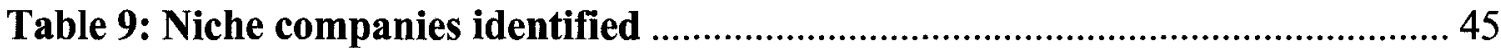




\section{LIST OF FIGURES}

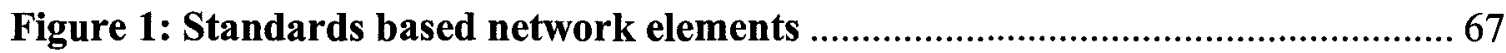

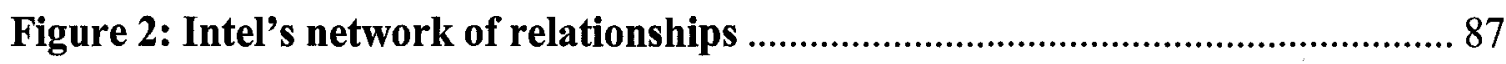

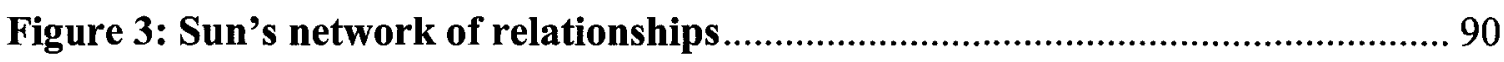

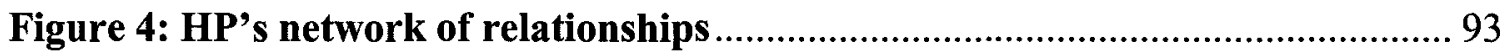

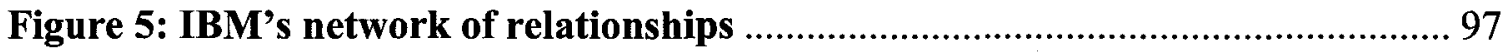

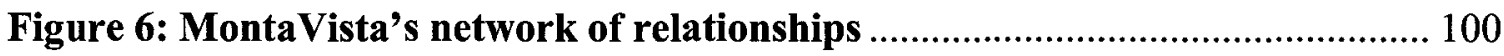

Figure 7: Wind River's network of relationships ............................................... 103

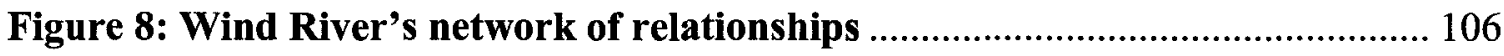

Figure 9: Ericsson's network of relationships.................................................. 109

Figure 10: NTT's network of relationships ................................................... 112 


\section{LIST OF APPENDICES}

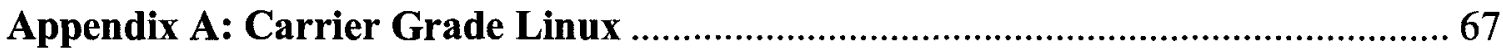

Appendix B: Members of CGL Working Group as of May 2005 .......................... 68

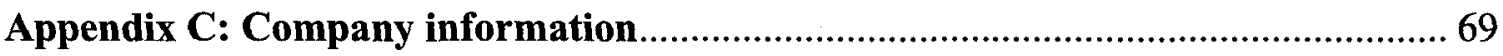

Appendix D: Motivations for companies to incorporate CGL specifications into

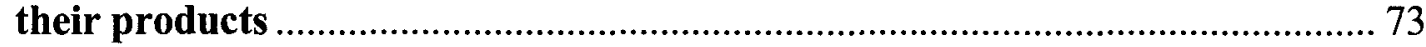

Appendix E: Actions carried out to create value from CGL initiative..................... 79

Appendix F: Actions carried out to appropriate value that was created with CGL

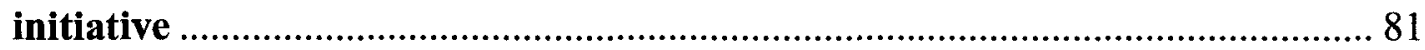

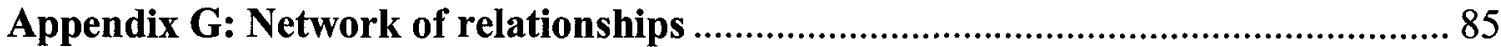

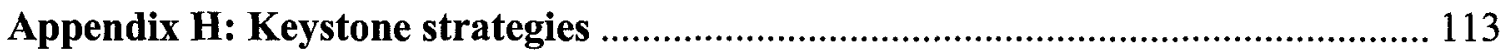

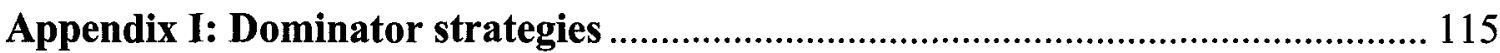




\section{INTRODUCTION}

This research uses two theoretical perspectives to make sense of company interactions with the Carrier Grade Linux (CGL) open platform ${ }^{1}$.

The CGL Working Group was founded by the Open Source Development Labs (OSDL) ${ }^{2}$ in 2002 to accelerate the adoption of Linux in the telecommunications industry. The CGL Working Group develops Linux specifications to satisfy carrier grade requirements. Appendix A provides a description of the initiatives of the CGL Working Group. Appendix B includes a list of companies that were members of CGL Working Group as of May 2005. These members include silicon providers, system suppliers, Linux distributors, telecom equipment manufactures, network equipment providers, integration and service providers, application providers and carriers. The last column of Appendix B identifies the companies which were included in the sample used in this research.

There are two reasons the CGL Working Group was chosen as the focus of this research. First, companies that sell telecommunications products and services have quickly adopted the specifications developed by the CGL Working Group. As of 2006, the CGL Working Group had issued four major releases, seven companies provided CGL 2.0 registered distributions, and dozens of companies offered CGL products (Haddad, 2006).

The second reason the CGL Working Group was selected for study is that it is an interesting case of a coalition game and business ecosystem. Companies that are

\footnotetext{
${ }^{1}$ An open platform is a platform developed using established industry standards and common practices.

${ }^{2}$ In 2007, the OSDL merged with the Free Standards Group to form The Linux Foundation.
} 
members of the CGL Working Group cooperate and compete with each other. Each company cooperates with others to increase the value they all derive from the CGL initiative, and competes to increase the proportion of the value it can appropriate. In this business game, no single company owns the platform that anchors the business ecosystem and all companies can use it.

\subsection{Objectives}

This research uses theory to examine publicly available information on companies that are members of the CGL Working Group for the purpose of answering three questions and generate insights. The research questions are:

- What motivates companies to incorporate CGL specifications into their market offers?

- How do companies that incorporate CGL specifications into their products create and appropriate value?

- What roles do specific companies play in the business ecosystem anchored around the CGL Working Group initiative?

\subsection{Deliverables}

The deliverables of this research are:

- Answers to the three research questions

- Insights generated from using theory to make sense of what is occurring around the 
adoption of CGL platforms

\subsection{Contributions}

The telecommunications industry is moving away from building communications and data service networks using proprietary platforms comprised of specialized hardware and proprietary technologies and interfaces towards building them using open platforms. These platforms are comprised of commercial-off-the-shelf (COTS) and open source components and building processes. This research makes at least two contributions to the emerging literature on open platforms. First, it identifies the ways companies that provide CGL compliant products use to appropriate value.

The second contribution this research makes is that it identifies the roles that specific companies play in a business ecosystem anchored around open platforms. Results suggest that, in the business ecosystem anchored around the CGL open platform:

- Multiple keystone companies coexist

- All keystone companies are system suppliers, but not all system suppliers are keystone companies

- Dominator companies do not exist

- All commercial distributors of open source assets are niche players. 


\subsection{Relevance}

This research is relevant to top management teams who are considering joining an open platform organization such as the CGL Working Group. Top management teams can use the outcomes of this research to assess the opportunity of participating in organizations like the CGL Working Group.

Academics may be interested on how theory can be used to examine competitive actions of companies that are part of ecosystems anchored on open platforms.

\subsection{Organization}

This thesis is organized into six chapters. Chapter 1 is the introduction. Chapter 2 provides the literature review and identifies the lessons learned from preparing it. Chapter 3 describes the research method. Chapter 4 presents the results of the research. Chapter 5 discusses the results of the research. Chapter 6 provides the conclusions, limitations, and suggestions for future research. 


\section{LITERATURE REVIEW}

Six streams of literature were reviewed. Section 2.1 reviews the literature on companies' motivations for participating in open source projects. Section 2.2 reviews the literature on value creation and appropriation. Section 2.3 reviews the literature on business ecosystems. Section 2.4 reviews the literature on network externalities. Section 2.5 reviews the literature on software platforms. Section 2.6 reviews the literature on open source risks and strategies. Finally, section 2.7 summarizes the lessons learned.

\subsection{Companies' motivations for participating in open source projects}

Companies participate in open source projects for the following motivations:

\section{Eliminate suppliers' lock-in}

Rossi and Bonaccorsi (2004a) argue that the open licenses make firms independent from the price and license policies of large software companies. Henkel (2003) argues that decreasing dependency on suppliers was an important reason for companies to participate in open source projects.

\section{Sell complementary products and services}

Companies can generate revenue by selling products and services that complement open source software (Henkel, 2003; Raymond 1999; Hecker 1999; Wichmann, 2002). For instance, HP and IBM sell hardware compatible with Linux; IBM provides support and consultant services for open source software; and Red Hat and SuSE sell distribution services based on Linux. 


\section{Enable users to innovate}

Open source projects enable users to innovate by themselves from design to distribution using the Web (von Hippel \& von Krogh, 2003).

\section{Access skilled personnel}

Through open source projects, companies can identify and contact talented programmers (Wichmann, 2002b; Rossi \& Bonaccorsi, 2004a).

\section{Reduce company's development and operating costs}

By using open source products, companies reduce their costs. Companies, especially small companies, can exploit assets developed by open source projects to reduce the cost of innovation (Rossi \& Bonaccorsi, 2004a). Companies can eliminate license fees and reduce hardware costs (Feller \& Fitzgerald, 2002; Tuma, 2005). Hawkins (2004) observed that firms reduced their costs by either using open source or releasing code. Contributions and feedbacks from open source communities help companies improve the quality and popularity of their products and reduce their expenditures (Rossi \& Bonaccorsi, 2004; Heckel, 2003; Goldman \& Gabreil, 2005; Wichmann, 2002a).

\section{Enter a new market}

Open source products can help a company enter a new market. This is the case of Linux entering a market dominated by Microsoft Windows (Rossi \& Bonaccorsi, 2004b) 


\section{Increase market share}

Netscape released Mozilla as open source to increase its market share in the browser market dominated by Microsoft IE (Raymond, 1999b). Similarly, HP, Oracle and IBM released proprietary code as open source to compete with their rivals that had dominant market positions (Lerner \& Tirole, 2002).

\section{Intrinsic community based}

Companies participate in open source projects for their intrinsic community-based incentives (Rossi \& Bonaccorsi, 2004b). The intrinsic motivations include conforming to the values of open source community (e.g., transparency and meritocracy), sharing knowledge with the community, and fighting for software freedom.

\subsection{Value creation and appropriation}

Bowmam and Ambrosini (2000) distinguish between use value and exchange value. They argue that use value is what customers perceive while exchange value is realized the point of sale. Perceived use value is defined as the price the customers are willing to pay, and exchange value is defined as the price paid by the buyer. In the process of value creation, new perceived use value is created by combining acquired use value with the labor of organizational members. Added exchange value (profit) is created when the exchange value realized is more than the cost of input. Bowmam and Ambrosini (2000) argue that whereas labor creates value, value appropriation is determined by perceived bargaining relationships between resource buyers and resource providers. 
Brandenburger and Stuart (1996) define the value created and added value in cooperative game situations. They define the value created by a company along with its suppliers and buyers in a vertical chain. The value created by the vertical chain of players is defined as the willingness of buyers to pay of minus the opportunity cost of suppliers. The added value of a player is defined as the value created by all players minus the value created by all other players. Given unrestricted bargaining, added value sets an upper bound on the maximum value a company can capture. Based on the definitions, they demonstrate four ways to achieve positive added value by creating asymmetries between a focal company and other companies: (i) raise the willingness to pay of buyers for the focal company's product, (ii) reduce suppliers' costs of doing business with the focal company, (iii) lower the willingness to pay of buyers for other companies' products, and (iv) raise suppliers' costs of providing resources to other companies.

MacDonald and Ryall (2004) expand the concept of value-based strategy by defining competitive advantage as the lower bound of the value a company can appropriate. A positive marginal product is a necessary condition that determines the competitive advantage is positive, whereas a positive minimum residual is a sufficient condition for positive competitive advantage. MacDonald and Ryall (2004) analyze the relationship between competitive advantage and inimitability. They claim that with unlimited product imitation, no company has competitive advantage, and with capability imitation, companies may have competitive advantage. A company that has a unique and valuable innovation, which is also used by its competitors does not necessarily enjoy a competitive advantage. 
Gans, MacDonald and Ryall (2006) extend the concept of competitive advantage from qualitative speculation to a quantitative assessment that can be used in complex environments.

Brandenburger and Nalebuff (1996) conceptualize business as co-opetition where players are cooperating as well as competing with each other. They proposed a Value Net framework with five elements: Players, Added values, Rules, Tactics and Scope. In the Value Net framework, a focal company has interactions with its customers, suppliers, competitors and complementors. All these players in the game are cooperating and competing with each other to create and appropriate value.

To appropriate value, players in the game may change the five elements in the Value Net framework. A player can bring in a new player to the game; try to protect and increase its added value; change the rules; use different tactics to change customers' perceptions; place a game in a larger scope to examine the relationships and impacts between games. To capture value in a coalition game, players must assess their position in the game and change the game to favor them.

Liu (2006) used the Value Net framework to examine the phenomenon of large companies releasing proprietary code as open source. This research identifies the changes of the five elements: players, added values, rules, tactics, and scope when companies such as Netscape, Apple, Sun, etc. released their code. The companies that release code 
as open source increase the total use value by improving the value of the code and lowering development and maintenance costs. Those companies capture value by limiting the value created by other players.

\subsection{Business ecosystem}

Moore (1996) defines business ecosystem as "an economic community supported by a foundation of interacting organizations and individuals--the organisms of the business world". The organizations in a business ecosystem include suppliers, lead producers, competitors, and other stakeholders. The organizations co-evolve with other organizations in the ecosystem which cross a variety of industries. One or more central companies are leaders to shape the directions of the ecosystem.

Moore (1993) defines four distinct stages in the life-cycle of a business ecosystem: birth, expansion, leadership and self-renewal/death and, for each stage, identifies cooperative and competitive challenges respectively.

In the birth stage, companies work with their customers and suppliers to discover the right value proposition around seed innovations; and protect their ideas from imitators.

During the expansion stage, companies work with suppliers and partners to obtain maximum market share. Companies stimulate market demand, provide adequate supply to meet the demand, and compete with other ecosystems. 
The leadership stage is when companies fight for control of the ecosystem in investment directions and technical standards. They have to build a stable structure gathering customers and suppliers, and they maintain their bargaining power with other players in the ecosystem by controlling key elements of value.

During the last stage, self-renewal, companies bring new innovations to the ecosystem and restructure to compete with new ecosystems. .

Iansiti and Levien (2004) conceptualize business networks as biological ecosystems. "Like biological ecosystems, business ecosystems are formed by large, loosely connected networks of entities". The members of business ecosystems share their fate with each other. They are influenced simultaneously by their internal capabilities and their interactions with other members. The overall health of the ecosystem has a critical effect on the health of individual members.

Iansiti and Levien (2004) identify three dimensions for the health of business ecosystems: productivity, robustness and niche creation. Productivity is usually measured by returns on invested capital. Robustness is primarily measured by survival rates which indicate an ecosystem's capability for facing and surviving perturbations and disruptions. Niche creation is measured as the increase in the diversity of companies and products in an ecosystem. 
Another important perspective introduced by Iansiti and Levien (2004) is that organizations take one of three different roles and choose operating strategies corresponding to their roles. The roles are: keystone, dominator and niche player.

Keystones are companies that actively improve the overall health of the ecosystem but with low physical presence. Keystones adopt strategies that create platforms and share the value with other players. Keystone companies have a significant effect on their ecosystems.

Dominators are companies that have physical presence and control a large part of their networks. Value dominators are referred to as landlords companies. Landlord companies have low physical presence but capture most of the value which is created by other players. Dominators take most the value for themselves and leave little for other players in the ecosystem.

Niche players are companies that specialize in capabilities differentiating themselves from others in the ecosystem. Niche players collectively create much of the value and capture the value they create. Niche players create value by using their unique capabilities leveraging capabilities from keystones. A key strategy to sharpen their niche offerings is sustaining innovations. A niche player must seek a balanced relationship with other players between tight coupling, which is more efficient, and loose coupling, which is more flexible. 


\subsection{Network externalities}

In the industrial economics literature, network effects or externalities are hypothesized to have major impacts on the market under environmental change and uncertainty. The literature distinguishes between direct and indirect network externalities (Katz \& Shapiro, 1985). The direct network externalities are generated when the number of users increases for consuming a product and the value of the product increases. The indirect network externalities are generated when the number of users of the components for the products increases. The increase of the value of one component often leads to the increase of the value of other components.

Users of a network are treated as being identical. Each user affects the network in the same way as the other users do. Suarez (2005) extended the theory of network effects by proposing strong-ties network effects and tested his theory in a technology adoption case in the wireless telecommunications industry. The strong-ties perspective drew on ideas from social network theory. This theory suggests that networks are not uniform and can be classified into strong vs. weak ties and direct vs. indirect ties. Small networks with strong ties tend to be more valuable for organizations than large networks with weak ties, particularly under uncertain circumstances.

Iyer, Lee, and Venkatraman (2006) describe implications of research findings to managers: map an ecosystem in terms of inter-firm interconnections, calibrate the network through key metrics, and examine the roles in the network and construct a network scorecard. 
Mapping the network of relationships and using network metrics can be helpful when developing successful business strategies (Iyer, Lee, \& Venkatraman, 2006). By illustrating the relationships among key players, the authors show that software companies resort to a virtual integration strategy through alliances to establish networks of influence and interoperability. The network metrics can be used to examine companies' relative network position in an ecosystem and brings a network perspective to strategic analysis. Three roles are defined by the characteristic of companies' connection with other companies: hub, broker and bridge.

\subsection{Software platform}

Evans and Schmalensee (2006) examine software platforms from the perspectives of the economics of a multisided platform. They argue that the ecosystem anchored around a software platform is comprised of two kinds of participants :(i) the end users of the systems built upon the software platform, and (ii) the complementors (providers of hardware, peripheral equipment, applications and content) that provide products that complement the software platform. The direct network effects arise when the number of users increases. The indirect network effects arise when the number of users of complements of the software platform increases.

Evans and Schmalensee (2006) identify two strategies used by software platform vendors to add applications on the platform: a multisided strategy or a single-sided strategy. In a multisided strategy, the software platform supports the interactions among the end users 
and the complementors. In a single-sided strategy, the platform buys the complements or produces itself.

A software platform can be either commercial or open source. Evans and Schmalensee (2006) argue that commercial methods of producing platforms are better than open source methods when managing the multisided aspects of the platform, while the open source method increases the reliability of the platform.

West (2003) examines the three proprietary platform vendors' decisions to replace their faltered proprietary platform strategies by open source platform strategies. Historically, these three companies (Apple, IBM and Sun) were promoting vertically integrated platforms built on proprietary software. To compete with Microsoft, these companies pursued hybrid strategies which take advantages of open source software while retaining control and differentiation. West (2006) argues that under the condition of competing imperatives, hybrid strategies can be used as an alternative for proprietary or open strategies. Two hybrid strategies were identified: (i) opening parts and (ii) partly open. A company pursues the opening parts strategy by waving the intellectual property rights of the commodity layers of the platform to attract competitors and key users and retaining control of other layers that can provide opportunities for differentiation. The company pursues the partly open strategy by disclosing technology under restrictions to attract customers and avoids collaboration with competitors. 


\subsection{Risks and strategies}

\subsubsection{Risks of companies participating in open source projects}

\section{Lose revenue}

A company that release code as open source forgoes revenues from licensing the proprietary software (Henkel, 2003; Gabreil \& Goldman, 2002).

\section{Lose competitive advantage}

A company's contributions to open source projects are accessible by all users, including competitors. Thus, a company that contributes to open source projects may lose its competitive advantage (Henkel, 2003; Gabreil \& Goldman, 2002).

\section{Lose control of the projects}

Company's objectives may conflict with the objectives of the open source community (Henkel, 2003; Lerner \& Tirole, 2004). The initial contributor of the open source project may lose its control over the project (Henkel, 2004).

\section{Intellectual property is not clear}

The infringement on intellectual property is one of the major concerns companies have for participating in open source projects. Companies need to allocate resources to ensure that their use of open source products does not infringe other companies' intellectual property rights. For example, the SCO Group sued IBM for using UNIX code in Linux. This law suit has been in the court for years. It affected IBM, IBM's customers and the open source community. 


\subsubsection{Open source business strategies}

Table 1 outlines the seven open source business strategies for competitive advantage identified by Koeing (2004).

\begin{tabular}{|c|c|c|}
\hline Strategies & Examples & Benefits \\
\hline $\begin{array}{l}\text { Optimization } \\
\text { strategy }\end{array}$ & $\begin{array}{l}\text { Oracle leverages and optimizes its } \\
\text { database solutions with Linux }\end{array}$ & $\begin{array}{l}\text { Reduce customers' cost } \\
\text { High margin for its products }\end{array}$ \\
\hline $\begin{array}{l}\text { Dual license } \\
\text { strategy }\end{array}$ & $\begin{array}{l}\text { MySQL and Sleepycat provide } \\
\text { commercial license and General } \\
\text { Public License(GPL) for their } \\
\text { customer }\end{array}$ & $\begin{array}{l}\text { Get larger user base and faster } \\
\text { adoption } \\
\text { Complement revenue through } \\
\text { services, consulting, training }\end{array}$ \\
\hline $\begin{array}{l}\text { Consulting } \\
\text { strategy }\end{array}$ & $\begin{array}{l}\text { 10X software provides integrated } \\
\text { consulting for open source software }\end{array}$ & Higher margin \\
\hline $\begin{array}{l}\text { Subscription } \\
\text { strategy }\end{array}$ & $\begin{array}{l}\text { Novell and Red Hat provide service } \\
\text { through subscription }\end{array}$ & Increase revenue \\
\hline $\begin{array}{l}\text { Patronage } \\
\text { strategy }\end{array}$ & $\begin{array}{l}\text { IBM make contributions to open } \\
\text { source projects }\end{array}$ & $\begin{array}{l}\text { Drive standards adoption } \\
\text { Crack entrenched markets }\end{array}$ \\
\hline Hosted strategy & $\begin{array}{l}\text { Google, Amazon and eBay use } \\
\text { GPL-licensed software internally }\end{array}$ & $\begin{array}{l}\text { Lower cost } \\
\text { Keep modification internal }\end{array}$ \\
\hline $\begin{array}{l}\text { Embedded } \\
\text { strategy }\end{array}$ & $\begin{array}{l}\text { Neoteris adopts Linux in its network } \\
\text { devices }\end{array}$ & $\begin{array}{l}\text { Reduce cost } \\
\text { Increase stability }\end{array}$ \\
\hline
\end{tabular}

Table 1: Seven open source business strategies 


\subsection{Lessons learned from literature review}

The following lessons were learned when preparing the literature reviews:

- Research results on how companies create and appropriate value from an open source platform are mostly high level and abstract. The literature does not identify specific actions that companies can carry out to create and appropriate value from an open source platform.

- Criteria that can be used to identify company roles in an ecosystem are lacking. The literature on business ecosystem defines the roles organizations play in a business ecosystem. The strategies of keystone, dominator and niche player are described by studying the cases of the companies like Microsoft, Wal-Mart, Enron, and IBM. However, concrete criteria that enables a researcher to examine information on a company and identify its role in the ecosystem do not exist.

- The ecosystems described in the literature are anchored around a company. There is a lack of research on the ecosystems anchored around an open platform that is not controlled by a single company.

- The literature on network of relationships provides a way to map an ecosystem through interconnections between companies in the ecosystem. The network metrics are used to examine companies' relative network positions in the network. The roles 
(hub, broker, bridge) in the literature are identified by companies' connections with other companies, while the roles (keystone, niche player or dominator) in business ecosystem literature are defined by the strategies the companies carry out. 


\section{RESEARCH METHOD}

This chapter describes the research method. Sections 3.1 and 3.2 identify the unit of analysis and the study period respectively. Section 3.3 describes the steps of the research method.

\subsection{Unit of analysis}

The unit of analysis is a company that as of May 2005 was a member of the CGL Working Group and developed and marketed products that incorporated CGL specifications.

\subsection{Study period}

The start of the study period was January 2002, the month the CGL Working Group was founded. The end of the study period was March 2007, the month data collection ended.

\subsection{Research method}

The research method used in this research, with one exception, was consistent with the one used by Liu (2006). In this research, the theoretical perspectives were used to identify the criteria for sample selection. Liu (2006) did not use the theoretical perspectives to set the sample selection criteria.

The research method used in this research comprised ten steps: 
1. Define research questions

2. Select theoretical perspectives

3. Select sample

4. Define categories for company's motivations, actions to create value, and actions to appropriate value

5. Set criteria to identify companies' roles

6. Collect data and build a database

7. Identify companies' motivations

8. Identify the actions to create and appropriated value

9. Calculate relationship metrics

10. Identify companies' roles

11. Answer research questions

12. Generate insights for managers and academics

\subsubsection{Define research questions}

The research questions were selected because they were of interest to the managers of the company that sponsored the research and the researcher.

The research questions were:

1. What motivates companies to incorporate CGL specifications into their market offers?

2. How do companies that incorporate CGL specifications into their products create and 
appropriate value?

3. What roles do specific companies play in the business ecosystem anchored around the CGL Working Group initiative?

\subsubsection{Select theoretical perspectives}

To answer the research questions, two theoretical perspectives were selected. Table 2 identifies the theoretical perspectives used in this research, the key references, and the reasons these perspectives were selected.

\begin{tabular}{|l|l|l|}
\hline \multicolumn{1}{|c|}{ Theory } & \multicolumn{1}{|c|}{ Key references } & \multicolumn{1}{c|}{ Perspective was selected to } \\
\hline Co-optition & $\begin{array}{l}\text { Brandenburger and Nalebuff } \\
(1996) \\
\text { Brandenburger and Stuart (1996) }\end{array}$ & $\begin{array}{l}\text { Examine the actions companies } \\
\text { carry out to create and capture value } \\
\text { derived from the CGL open } \\
\text { platform }\end{array}$ \\
\hline $\begin{array}{l}\text { Business } \\
\text { ecosystem }\end{array}$ & $\begin{array}{l}\text { Iansiti and Levien (2004) } \\
\text { Iyer, Lee, and Venkatraman (2006) }\end{array}$ & $\begin{array}{l}\text { Identify the roles companies play in } \\
\text { the ecosystem anchored around the } \\
\text { CGL open platform }\end{array}$ \\
\hline
\end{tabular}

Table 2: Rationale for selecting theoretical perspectives

\subsubsection{Select sample}

The criteria for sample selection were:

1. A company had to be a member of the CGL Working Group as of May 2005.

Appendix B shows that 24 companies were members of the CGL Working Group as of May 2005. 
2. The following information had to be available online on a company's web pages or press releases, CGL Working Group's web pages or press releases, and industry analysts' reports:

a. Reasons for the company to incorporate CGL specifications into their market offers

b. Actions undertaken by the company which the researcher deemed to add or appropriate value

c. Partnerships and relationships with other companies that were members of the CGL Working Group.

For each of the companies in Appendix B, the Google search engine was used to identify a company's press releases, CGL Working Group's press releases and industry analysts' reports that included the requisite information identified above. The keywords entered in the Google search utility included the name of the company followed by 'carrier grade Linux' and CGL.

If the requisite information for the company existed online, the company was included in the sample. 


\subsubsection{Define categories for companies' motivations, actions to create value, and actions to appropriate value}

\section{Company motivations}

Company motivations for incorporating CGL specifications into market offers were organized into the eight categories identified in Section 2.1 Companies motivations for participating in open source projects. These eight categories were:

1. Eliminate suppliers' lock-in

2. Sell complementary products and services

3. Enable users to innovate

4. Access skilled personnel

5. Reduce company's development and operating costs

6. Enter a new market

7. Increase market share

8. Intrinsic community based

New categories were to be added only if the researcher and the supervisor agreed that the information online could not be included in any of the existing eight categories for company motivations. Based on the analysis of the data collected, the categories could be detailed or segmented into subcategories.

\section{Actions leading to value creation}

Research by Brandenburger and Stuart (1996) discussed in Section 2.2 was used to define 
the categories into which to organize actions to create value.

Actions to create value from the CGL initiative were organized into three categories:

1. Actions to increase the number of users of CGL products

2. Actions to increase customers' willingness to pay for CGL products

3. Actions to decrease costs of providing CGL products

\section{Actions leading to value appropriation}

Research by Brandenburger and Stuart (1996) discussed in Section 2.2 was used to define the categories into which to organize actions to create value.

Actions to appropriate value that was created by the CGL open platform were organized into four categories:

1. Actions to increase customers' willingness to pay for the company's products

2. Decrease buyers' willingness to pay for competitors' products

3. Actions to decrease suppliers' cost to provide resources to the company

4. Actions to increase suppliers' cost to provide resources to competitors

New categories for value creation and value appropriation actions were to be added only if the researcher and the supervisor agreed that the information online could not be included in any of the existing four categories for actions to appropriate value. Based on the analysis of the data collected, the categories could be detailed or segmented into subcategories. 


\subsubsection{Collect data and build a database}

For each company in the sample, the following information was collected and entered into a database:

- Company's name

- Company's core business

- Company's products and services

- CGL related products and services sold by the company

- 2005 revenue

- Involved open source projects

- Products for telecommunications

- Participated technical alliances

- Motivations for incorporating CGL specifications into market offers

- Actions deemed by the researcher to lead to value creation

- Actions deemed by the researcher to lead to value appropriation

- Partnerships with each other company that was a member of the CGL Working Group that were built around market agreements, license agreements, research and development agreements and equity investments

- Customer, supplier, and complementor relationships with each other company that was a member of the CGL Working Group

- Whether or not the company developed a platform on which other companies can develop their products, provided solutions to benefit the ecosystem, created standards for information exchange between companies or regulated the connection between companies 
- Whether or not the company developed vertically integrated CGL products on its own

- Whether or not the company released proprietary code to the CGL open platform or contributed to the CGL Working Group

- Number of employees sitting as officers of the CGL Working Group

\subsubsection{Degree of links}

Based on the research work on micro-level network metrics reported by Iyer, Lee and Venkatraman (2006) a company's degree of links was measured by counting the number of companies that were members of the CGL Working Group with which the company had a partnership or a market relationship.

\subsubsection{Identify companies' roles}

Definitions provided by Iansiti and Levien (2004) in Section 2.3 and the degree of links were used to identify a company's role.

A company was a keystone company if:

1. The company's degree of links was ranked in the top four

2. The company developed a platform on which other companies can develop their products, provided solutions to benefit the ecosystem, created standards for information exchange between companies or regulated the connection between companies 
A company was a dominator company if:

1. The company's degree of links was ranked in the top four

2. The company developed vertically integrated CGL products on its own

3. Two of the company employees sat as officers of the CGL Working Group

A company was a niche player if it was not a keystone or a dominator company.

\subsubsection{Answer research questions}

This section describes how each question was answered.

\section{What motivates companies to incorporate CGL specifications into their market offers?}

For each company in the sample, data was examined to identify the company's motivations for providing CGL products (i.e., products that incorporated CGL specifications). A list of eight categories of motivations for companies to participate in open source projects was used to organize the information collected.

If the information found online does not fit the eight categories listed in Section 3.3.4, new categories will be added. Information can also be used to detail a category or create subcategories. 
Information on company motivations will be stored in a database and then summarized in a Table with company names as columns and motivations as cells. For each motivation in the table, a count will be provided to illustrate how many companies support the motivation category. Motivations for incorporating CGL specifications will be ranked in terms of this count. Motivations with a count of zero will be deemed not to affect the decision to incorporate CGL specifications into products.

\section{How do companies that incorporate CGL specifications into their products create and appropriate value?}

For each company selected as a sample of this research, data was examined to identify its actions to create and appropriate value. Two tables were formed for value creation and value appropriation separately. The tables include the categories of actions described in Section 3.3.4 and the detail information about the actions for each company. For each action listed in the table, a count was given to illustrate how many samples in this research support that action. A total count was also given at the end of the table.

\section{What roles do specific companies play in the business ecosystem anchored around the CGL Working Group initiative?}

For each company selected as a sample of this research, a figure was drawn to illustrate its connections with other companies that were members of CGL Working Group. The network metric, degree of links, was calculated by counting the connections. 
Three tables were formed to list the constructs described in Section 3.3.4 for keystone, dominator, or niche player separately. The data of each company was examined to identify the strategies undertaken by the company to shape its position in the CGL Working Group. A company's role was determined if its strategies met the criteria for the role.

\subsubsection{Generate insights for managers and academics}

A set of insights deemed to be of value to top management teams and academics were generated and iterated various times to incorporate the feedback received during the Gate 0 and Gate 1 presentations.

A draft of the insights generated from the research was provided to the managers who sponsored the research. A revised draft of these insights that incorporated managers' feedback was produced and included in the thesis. 


\section{RESULTS}

\subsection{Sample}

Of the 24 companies listed in Appendix B, nine companies ( $38 \%$ of the 24 ) met the criteria defined in Section 3.3.3. The sample was comprised of:

- Intel (Silicon provider)

- MontaVista, Wind River, Red Hat (Linux providers)

- IBM, HP, Sun (System suppliers)

- Ericsson (Network equipment supplier)

- NTT (Carrier)

Appendix B shows that five of the seven types of members are represented in the sample. The sample does not include integration service providers and middleware application providers.

Appendix C shows following information collected for the nine companies: core business, products and service, CGL related products, 2005 revenue, involved open source projects, products for telecommunications, and participated technical alliances.

\subsection{Data sources}

Information for this research was drawn from the following data sources:

- Companies' websites

- CGL Working Group (old.linux-foundation.org/lab_activities/carrier_grade linux) 
- Business Week (www.businessweek.com)

- EETimes (www.eetimes.com)

- Eweek (www.eweek.com)

- Info World (www.infoworld.com)

- Internet News (www.internetnews.com)

- Linux (Linux.sys-con.com)

- Linux Devices (www.linuxdevices.com)

- Linux Planet (www.linuxplanet.com)

- Linux Watch (www.linux-watch.com)

- Reuters (www.reuters.com)

- TechRepublic (techrepublic.com.com)

- Tech World (www.techworld.com)

- ZDNet (news.zdnet.com)

\subsection{Motivations}

Appendix D shows the information on the motivations that companies have to incorporate CGL into their products. The information shown in Appendix D was collected from companies' news releases and analysts' reports that were found carrying out online searches. The information was organized by the researcher into the categories for companies' motivations to participate in open source projects described in Section 2.1.1 of the literature review and listed in Section 3.3.4. 
Table 3 provides a summary of the information in Appendix D. An ' $X$ ' indicates that information on the company shown in the column supports the motivation shown in the row. The last column is a count of the number of $\mathrm{Xs}$ in a given row.

Table 3 shows that:

- Two new motivation categories were drawn from the data (Categories 9 and 10). Both focused on customers. Category 9 comprises statements about using the CGL open platform to add value to customers while Category 10 comprises statements about using CGL to introduce differentiated products that customers wish to buy.

- Category 2 had the most entries, it accounted for seven of the 24 'X's shown in Table 3.

- Categories 3, 4 and 8 had no entries. 


\begin{tabular}{|c|c|c|c|c|c|c|c|c|c|c|}
\hline & \multicolumn{9}{|c|}{ Companies in sample } & \multirow[t]{2}{*}{ Count } \\
\hline Motivations & Intel & Sun & $\mathbf{H P}$ & IBM & $\begin{array}{c}\text { Monta- } \\
\text { Vista }\end{array}$ & $\begin{array}{l}\text { Wind } \\
\text { River }\end{array}$ & $\begin{array}{l}\text { Red } \\
\text { Hat }\end{array}$ & Ericsson & NTT & \\
\hline \multicolumn{11}{|l|}{$\begin{array}{l}\text { Identified in } \\
\text { Section 2.1.1 } \\
\end{array}$} \\
\hline $\begin{array}{l}\text { 1. Eliminate } \\
\text { suppliers' lock- } \\
\text { in }\end{array}$ & & & & $\mathrm{X}$ & & & & & $\mathrm{X}$ & 2 \\
\hline $\begin{array}{l}\text { 2. Sell } \\
\text { complementary } \\
\text { products and } \\
\text { services }\end{array}$ & $\mathrm{X}$ & $\mathrm{X}$ & $\mathrm{X}$ & $\mathrm{X}$ & $\mathrm{X}$ & $\mathrm{X}$ & $\bar{X}$ & & & 7 \\
\hline $\begin{array}{l}\text { 3. Enable users } \\
\text { to innovate }\end{array}$ & & & & & & & & & & 0 \\
\hline $\begin{array}{l}\text { 4. Access skilled } \\
\text { personnel }\end{array}$ & & & & & & & & & & 0 \\
\hline $\begin{array}{l}\text { 5. Reduce } \\
\text { company's } \\
\text { development or } \\
\text { operating costs }\end{array}$ & & & & & & & & $\bar{X}$ & $\mathrm{X}$ & 2 \\
\hline $\begin{array}{l}\text { 6. Enter a new } \\
\text { market }\end{array}$ & $\bar{X}$ & & & & $\mathrm{X}$ & & & & & 2 \\
\hline $\begin{array}{l}\text { 7. Increase } \\
\text { market share }\end{array}$ & & & $\mathrm{X}$ & $\bar{X}$ & & & $\mathrm{X}$ & & & 3 \\
\hline $\begin{array}{l}\text { 8. Intrinsic } \\
\text { community } \\
\text { based }\end{array}$ & & & & & & & & & & 0 \\
\hline \multicolumn{11}{|l|}{ New from data } \\
\hline $\begin{array}{l}\text { 9. Increase value } \\
\text { for customers }\end{array}$ & $\bar{X}$ & & $\mathrm{X}$ & $\bar{X}$ & $\bar{X}$ & $\mathrm{X}$ & & $\mathrm{X}$ & & 6 \\
\hline $\begin{array}{l}\text { 10. Introduce } \\
\text { differentiated } \\
\text { products }\end{array}$ & & & & & $\mathrm{X}$ & $\mathrm{X}$ & & & & 2 \\
\hline & & & & & & & & Total & ount & 24 \\
\hline
\end{tabular}

Table 3: Motivations for companies to incorporate CGL into their market offers 


\subsection{Value creation}

Appendix E shows the information on the actions that companies in the sample carried out which, in the opinion of the researcher, can be included into the three value creation categories identified in Section 3.3.4.

The information shown in Appendix E was collected from companies' news releases and analysts' reports that were found online.

Table 4 provides a summary of the information in Appendix E. An ' $X$ ' indicates that information on the company shown in the column supports the action to create value shown in the row. The last column is a count of the number of Xs in a given row.

Table 4 shows that:

- All nine companies in the sample reported carrying out actions to increase the number of users of CGL products, and these were comprised of actions carried out to introduce new products that incorporated CGL specifications and actions to incorporate CGL specifications into existing products.

- All nine companies reported carrying out actions to increase customers' willingness to pay for CGL products. These actions can be grouped into two types: actions carried out to release proprietary code into the CGL initiative and support CGL projects (7 companies) and actions carried out to establish partnerships with customers and complementors ( 9 companies). 
- Only two companies, the equipment supplier and the carrier, reported carrying out actions to decrease their development and operating costs. 


\begin{tabular}{|c|c|c|c|c|c|c|c|c|c|c|}
\hline $\begin{array}{l}\text { Actions to } \\
\text { create value } \\
\text { from CGL } \\
\text { initiative }\end{array}$ & Intel & Sun & HP & IBM & $\begin{array}{c}\text { Monta- } \\
\text { Vista }\end{array}$ & $\begin{array}{l}\text { Wind } \\
\text { River }\end{array}$ & $\begin{array}{l}\text { Red } \\
\text { Hat }\end{array}$ & Ericsson & NTT & Count \\
\hline $\begin{array}{l}\text { Identified in } \\
\text { Section 3.3.4 }\end{array}$ & & & & & & & & & & \\
\hline $\begin{array}{l}\text {.Actions to } \\
\text { increase the } \\
\text { number of users } \\
\text { of CGL products }\end{array}$ & $\mathrm{X}$ & $\mathrm{X}$ & $\mathrm{X}$ & $\bar{X}$ & $\bar{X}$ & $\mathrm{X}$ & $\bar{X}$ & $\mathrm{X}$ & $\bar{X}$ & 9 \\
\hline $\begin{array}{l}\text { 1A.Introduced } \\
\text { new CGL } \\
\text { products or } \\
\text { incorporated } \\
\text { CGL } \\
\text { specifications in } \\
\text { existing products }\end{array}$ & $\bar{X}$ & $\mathrm{X}$ & $\bar{X}$ & $\bar{X}$ & $\mathrm{X}$ & $\mathrm{X}$ & $\mathrm{X}$ & $\bar{X}$ & $\mathrm{X}$ & 9 \\
\hline $\begin{array}{l}\text { 2.Actions to } \\
\text { increase } \\
\text { customers' } \\
\text { willingness to } \\
\text { pay for CGL } \\
\text { products }\end{array}$ & $\bar{X}$ & $\mathrm{X}$ & $\bar{X}$ & $\mathrm{X}$ & $\mathrm{X}$ & $\mathrm{X}$ & $\mathrm{X}$ & $\mathrm{X}$ & $\bar{X}$ & 9 \\
\hline $\begin{array}{l}\text { 2.A. Released } \\
\text { proprietary code } \\
\text { into CGL or } \\
\text { supported CGL } \\
\text { projects }\end{array}$ & $\mathrm{X}$ & & $\mathrm{X}$ & $\mathrm{X}$ & $\bar{X}$ & $\mathrm{X}$ & & $\bar{X}$ & $\mathrm{X}$ & 7 \\
\hline $\begin{array}{l}\text { 2.B.Established } \\
\text { partnerships with } \\
\text { customers and } \\
\text { complementors }\end{array}$ & $\bar{X}$ & $\mathrm{X}$ & $\mathrm{X}$ & $\bar{X}$ & $\bar{X}$ & $\bar{X}$ & $\mathrm{X}$ & $\mathrm{X}$ & $\bar{X}$ & 9 \\
\hline $\begin{array}{l}\text { 3. Actions to } \\
\text { decrease } \\
\text { company's } \\
\text { development or } \\
\text { operating costs }\end{array}$ & & & & & & & & $\mathrm{X}$ & $\bar{X}$ & 2 \\
\hline New from data & & & & & & & & & & \\
\hline \multicolumn{10}{|c|}{ Total $X$ count } & 27 \\
\hline
\end{tabular}

Table 4: Actions carried out to create value from CGL initiative 


\subsection{Value appropriation}

Appendix $\mathrm{F}$ shows the information on the actions that companies in the sample carried out which, in the opinion of the researcher, can be included into the four value appropriation categories identified in Section 3.3.4.

The information shown in Appendix F was collected from companies' news releases and analysts' reports that were found online.

Table 5 provides a summary of the information in Appendix F. An ' $\mathrm{X}$ ' indicates that information on the company shown in the column supports the action to create value shown in the row. The last column is a count of the number of Xs in a given row. 


\begin{tabular}{|c|c|c|c|c|c|c|c|c|c|c|}
\hline $\begin{array}{l}\text { Actions to } \\
\text { appropriate } \\
\text { value created }\end{array}$ & Intel & Sun & $\mathbf{H P}$ & IBM & $\begin{array}{l}\text { Monta } \\
\text { Vista }\end{array}$ & $\begin{array}{l}\text { Wind } \\
\text { River }\end{array}$ & $\begin{array}{l}\text { Red } \\
\text { Hat }\end{array}$ & Ericsson & NTT & Count \\
\hline $\begin{array}{l}\text { Identified in } \\
\text { Section 3.3.4 }\end{array}$ & & & & & & & & & & \\
\hline $\begin{array}{l}\text { 1.Increase buyers' } \\
\text { willingness to pay } \\
\text { for the company's } \\
\text { products }\end{array}$ & $\mathrm{X}$ & $\mathrm{X}$ & $\mathrm{X}$ & $\bar{X}$ & $\bar{X}$ & $\mathrm{X}$ & $\mathrm{X}$ & $\mathrm{X}$ & $\mathrm{X}$ & 9 \\
\hline $\begin{array}{l}\text { 1.A.Provided } \\
\text { differentiated } \\
\text { products }\end{array}$ & $\mathrm{X}$ & $\mathrm{X}$ & $\mathrm{X}$ & $\mathrm{X}$ & $\bar{X}$ & $\bar{X}$ & $\bar{X}$ & $\bar{X}$ & $\bar{X}$ & 9 \\
\hline $\begin{array}{l}\text { 1.B.Established } \\
\text { partnership with } \\
\text { companies that } \\
\text { are not CGL } \\
\text { members but } \\
\text { provide } \\
\text { complements for } \\
\text { CGL }\end{array}$ & $\mathrm{X}$ & & & $\mathrm{X}$ & & & $\mathrm{X}$ & & & 3 \\
\hline $\begin{array}{l}\text { 1.C.Provided } \\
\text { migration } \\
\text { program for } \\
\text { competitors' } \\
\text { customers }\end{array}$ & & $\bar{X}$ & $\mathrm{X}$ & $\bar{X}$ & & $\mathrm{X}$ & & & & 4 \\
\hline $\begin{array}{l}\text { 2.Decrease } \\
\text { buyers' } \\
\text { willingness to pay } \\
\text { for competitors' } \\
\text { products }\end{array}$ & & & $\mathrm{X}$ & & & & & & & 1 \\
\hline $\begin{array}{l}\text { 2.A.Provided free } \\
\text { CGL distribution }\end{array}$ & & & $\bar{X}$ & & & & & & & 1 \\
\hline $\begin{array}{l}\text { 3.Decrease } \\
\text { suppliers' cost to } \\
\text { provide resources } \\
\text { to the company }\end{array}$ & $\mathrm{X}$ & $\mathrm{X}$ & $\mathrm{X}$ & $\bar{X}$ & & & & $\bar{X}$ & $\bar{X}$ & 6 \\
\hline $\begin{array}{l}\text { 3.A.Established } \\
\text { partnerships with } \\
\text { suppliers }\end{array}$ & $\mathrm{X}$ & $\mathrm{X}$ & $\mathrm{X}$ & $\mathrm{X}$ & & & & $\mathrm{X}$ & $\mathrm{X}$ & 6 \\
\hline $\begin{array}{l}\text { 4.Increase } \\
\text { suppliers' } \\
\text { opportunity cost } \\
\text { to provide } \\
\text { resources to } \\
\text { competitors } \\
\end{array}$ & & & & & & & & & & 0 \\
\hline \multicolumn{10}{|c|}{ Total X count } & 22 \\
\hline
\end{tabular}

Table 5: Actions carried out to appropriate value 
Table 5 shows that:

- All nine companies in the sample reported carrying out actions to increase buyers' willingness to pay for the company's products. These actions can be grouped into three types: actions carried out to provide differentiated products, actions to establish partnerships with companies that are not CGL members but provide complementary products to CGL, and actions to provide migration programs for competitors' customers.

- Only one company reported carrying out actions to decrease buyers' willingness to pay for competitors' products. This company provided CGL distribution.

- Six companies reported carrying out actions to decrease suppliers' costs of providing resources to the company. These companies established partnerships with suppliers.

- No company in the sample reported actions to increase suppliers' opportunity cost to provide resources to competitors. 


\subsection{Network metrics}

For each company in the sample, Appendix G provides maps of its partnerships and relationships. Table 6 provides the degree of links calculated by using the information shown in Appendix G.

\begin{tabular}{|l|c|}
\hline & Degree of Links \\
\hline IBM & 22 \\
\hline Sun & 21 \\
\hline Intel & 20 \\
\hline HP & 17 \\
\hline NTT & 15 \\
\hline Red Hat & 12 \\
\hline Ericsson & 12 \\
\hline MontaVista & 9 \\
\hline Wind River & 9 \\
\hline
\end{tabular}

Table 6: Degree of links for companies in the sample

The four companies that had the largest degrees of links were: IBM, Sun, Intel and HP. 


\subsection{Companies' roles}

Using the criteria in Section 3.3.7, each company in the sample was identified as a keystone, dominator, or niche company.

\section{Keystone companies}

Table 7 provides a summary of the information in Appendix $H$. An ' $X$ ' indicates that information on the company shown in the column supports the constructs shown in the row.

IBM, HP and Intel were identified as keystone companies. These three companies had degrees of links ranked in the top four and either developed a platform on which other companies can develop their products (HP and IBM) or provided solutions that benefited the ecosystem (Intel).

None of the companies in the sample created standards for information exchange between companies or regulated the connections between companies. 


\begin{tabular}{|c|c|c|c|c|c|c|c|c|c|}
\hline $\begin{array}{l}\text { Keystone } \\
\text { criteria }\end{array}$ & Intel & Sun & $\mathbf{H P}$ & IBM & $\begin{array}{c}\text { Monta- } \\
\text { Vista }\end{array}$ & $\begin{array}{l}\text { Wind } \\
\text { River }\end{array}$ & $\begin{array}{l}\text { Red } \\
\text { Hat }\end{array}$ & Ericsson & NTT \\
\hline $\begin{array}{l}\text { 1. Company's } \\
\text { degree of links } \\
\text { was ranked in } \\
\text { top } 4\end{array}$ & $\mathrm{X}$ & $\mathrm{X}$ & $\mathrm{X}$ & $\bar{X}$ & & & & & \\
\hline $\begin{array}{l}2 \mathrm{~A} . \\
\text { Developed a } \\
\text { platform on } \\
\text { which other } \\
\text { companies can } \\
\text { developed their } \\
\text { products }\end{array}$ & & & $\mathrm{X}$ & $\mathrm{X}$ & & & & & \\
\hline $\begin{array}{l}\text { 2B. } \\
\text { Provided } \\
\text { solutions to } \\
\text { benefit the } \\
\text { ecosystem }\end{array}$ & $\mathrm{X}$ & & & & & & & & \\
\hline $\begin{array}{l}2 \mathrm{C} . \\
\text { Created } \\
\text { standards for } \\
\text { information } \\
\text { exchange } \\
\text { between } \\
\text { companies } \\
\end{array}$ & & & & & & & & & \\
\hline $\begin{array}{l}2 \mathrm{D} . \\
\text { Regulated } \\
\text { connection } \\
\text { between } \\
\text { companies }\end{array}$ & & & & & & & & & \\
\hline $\begin{array}{l}\text { Keystone } \\
\text { companies } \\
\text { identified } \\
\end{array}$ & $\mathrm{X}$ & & $\mathrm{X}$ & $\mathrm{X}$ & & & & & \\
\hline
\end{tabular}

Table 7: Keystone companies identified

\section{Dominator companies}

Table 8 provides a summary of the information in Appendix I. An ' $\mathrm{X}$ ' indicates that information on the company shown in the column supports the constructs shown in the row.

No company was identified as being in the dominator role. 


\begin{tabular}{|c|c|c|c|c|c|c|c|c|c|}
\hline $\begin{array}{l}\text { Dominator } \\
\text { criteria }\end{array}$ & Intel & Sun & HP & IBM & $\begin{array}{l}\text { Monta- } \\
\text { Vista }\end{array}$ & $\begin{array}{l}\text { Wind } \\
\text { River }\end{array}$ & $\begin{array}{l}\text { Red } \\
\text { Hat }\end{array}$ & Ericsson & NTT \\
\hline $\begin{array}{l}\text { 1. Company's } \\
\text { degree of links } \\
\text { was ranked in } \\
\text { top } 4\end{array}$ & $\mathrm{X}$ & $\bar{x}$ & $X$ & $\mathrm{X}$ & & & & & \\
\hline $\begin{array}{l}2 . \\
\text { Company } \\
\text { developed } \\
\text { vertically } \\
\text { integrated CGL } \\
\text { products on its } \\
\text { own }\end{array}$ & & & & & & & & & \\
\hline $\begin{array}{l}3 . \\
\text { Two or more } \\
\text { employees sit as } \\
\text { officers of the } \\
\text { CGL Working } \\
\text { Group }\end{array}$ & & & & & $\bar{X}$ & & & & \\
\hline $\begin{array}{l}\text { Dominator } \\
\text { Companies } \\
\text { identified }\end{array}$ & & & & & & & & & \\
\hline
\end{tabular}

Table 8: Dominator companies identified

\section{Niche companies}

Table 9 provides a summary of the information in Tables 7 and 8 . According to Section

3.3.7, a niche company was one that was not a keystone or a dominator company.

Sun, MontaVista, Wind River, Red Hat, Ericsson and NTT were identified as niche companies. 


\begin{tabular}{|l|c|c|c|c|c|c|c|c|c|}
\hline Niche criteria & Intel & Sun & HP & IBM & $\begin{array}{c}\text { Monta- } \\
\text { Vista }\end{array}$ & $\begin{array}{c}\text { Wind } \\
\text { River }\end{array}$ & $\begin{array}{c}\text { Red } \\
\text { Hat }\end{array}$ & Ericsson & NTT \\
\hline $\begin{array}{l}\text { 1. Keystone } \\
\text { company (Table } \\
\text { 9) }\end{array}$ & $\mathrm{X}$ & & $\mathrm{X}$ & $\mathrm{X}$ & & & & & \\
\hline $\begin{array}{l}\text { 2. Dominator } \\
\text { company (Table } \\
\text { 10) }\end{array}$ & & & & & & & & & \\
\hline $\begin{array}{l}\text { 3. Niche } \\
\text { company }\end{array}$ & & $\mathrm{X}$ & & & $\mathrm{X}$ & $\mathrm{X}$ & $\mathrm{X}$ & $\mathrm{X}$ & $\mathrm{X}$ \\
\hline
\end{tabular}

Table 9: Niche companies identified 


\section{DISCUSSION OF RESULTS}

This chapter answers the research questions, generates insights of interest to managers and academics, and discusses the results.

\subsection{Answer to research questions}

\subsubsection{What motivates companies to incorporate CGL specifications into their market offers?}

The information in Table 3 and Appendix D suggest that seven motivations drive companies to incorporate CGL specifications into their market offers. Five of the seven are product/market or customer expansion motivations, one is a cost reduction motivation, and one is supply-chain management motivation.

These motivations for companies to incorporate CGL specifications into their market offers are:

1. Product/market or customer expansion motivations
a. Increase value for customers
b. Introduce differentiated products
c. Increase market share
d. Enter a new market
e. Sell complementary products and services

2. Cost reduction motivation

a. Reduce company's development or operating costs 
3. Supply-chain management motivation

a. Eliminate supplier lock-in

\subsubsection{How do companies that incorporate CGL specifications into their products create and appropriate value?}

Information in Tables 4 and 5 and Appendices $\mathrm{E}$ and $\mathrm{F}$ suggest that companies carry out four actions to create value for the CGL open platform and five actions to appropriate the value created.

To create value for the CGL open platform, companies:

1. Introduced new CGL products or incorporated CGL specifications in existing products

2. Released proprietary code into the CGL initiative and supported CGL projects

3. Established partnerships with customers and complementors

4. Decreased development or operating costs

To appropriate value created, companies:

1. Provided differentiated products

2. Established partnerships with suppliers

3. Established partnerships with companies that are not members of the CGL Working Group but provide complementary products and services for CGL products

4. Provided migration programs for competitors' products

5. Provided free CGL distribution 


\subsubsection{What roles do specific companies play in the business ecosystem anchored around the CGL Working Group initiative?}

Table 9 shows that companies played one of two roles: keystone and niche. No company was identified in the dominator role.

HP, IBM and Intel were identified as being in the keystone role. The six other companies in the sample, Sun, MontaVista, Wind River, Red Hat, Ericsson and NTT, were identified in the niche company role. 


\subsection{Insights generated}

Seven insights were generated while completing this research. This section summarizes these insights.

1. Motivations for incorporating CGL specifications into products did not include three motivations for companies to participate in open source projects

2. The two founders of the CGL Working Group were non-telecommunications companies who then entered the market

3. Companies that were negatively affected by the CGL initiative subsequently adopted the CGL specifications

4. There is more than one keystone company

5. All keystone companies were system providers, but not all system providers were keystones

6. All three commercial Linux distributors were niche players

7. The relationships of alliance and financial connection, which were not illustrated in Value Net framework, may have important implications

\section{Motivations for incorporating CGL specifications into products did not include three motivations for companies to participate in open source projects} The literature (Rossi \& Bonaccorsi, 2004b) has identified eight motivations for companies to participate in open source projects. Motivations for incorporating CGL specifications into products did not include the following three motivations that 
companies have to participate in open source projects: (i) enable users to innovate, (ii) access skilled personnel, and (iii) intrinsic community based.

The two founders of the CGL Working Group were non-telecommunications companies who then entered the market

Intel and MontaVista founded the CGL Working Group at a time in which neither one operated in the telecommunications market. Intel was transforming from being a PCcentric chip maker to being a versatile information technology company targeting industries like consumer electronics, wireless communication, and health care. Intel is actively shaping the open platform based on the Intel architecture and Linux operating system with the aim to take the high-end server market away from Sun.

To expand its market for Linux distributions, MontaVista worked closely with the leading telecommunications equipment makers to define the CGL specifications.

The CGL open platform has enabled its two founders to successfully enter the telecommunications market.

\section{Companies that were negatively affected by the CGL initiative subsequently adopted the CGL specifications}

Sun had a well established presence in the telecommunications market before the initiation of the CGL Working Group. Sun dominated the telecommunications server 
market. The CGL initiative with its Intel architecture and Linux operating system was a significant threat to Sun.

Today Sun is one of the two companies that were CGL members that have not contributed to CGL projects. However, Sun has adopted CGL specifications into its products.

Before the inception of the CGL Working Group, Wind River was a major supplier to the telecommunications industry providing VxWorks, a hard real-time operating system. Wind River chose BSD UNIX over Linux and then realized the choice was a mistake. Wind Rivers has accepted the CGL specifications, as positions Linux as a complement to its VxWorks product lines.

\section{There is more than one keystone company}

Three keystone companies coexist in the CGL ecosystem. Iansiti and Levien (2004) assume one keystone company in each ecosystem. In a traditional business ecosystem, the keystone company generally is the central hub of the network and has crucial impact on other players. Keystones of a traditional business ecosystem provide platforms on which other players depend, and the removal of the keystone company would lead to the collapse of the entire ecosystem.

In the CGL ecosystem, three keystone companies were identified. The core of the ecosystem, the open platform, was accessible to any company and was not controlled by any keystone companies. The keystone companies had similar level of network 
connections; they did not have the same influence over the ecosystem as the those keystones described in the literature.

All keystone companies were system providers, but not all system providers were keystones

The three keystone companies, IBM, Intel and HP are system providers. However, Sun, which is also a system provider, is a niche player in the CGL ecosystem.

\section{All three commercial Linux distributors were niche players}

Red Hat, MontaVista and Wind River are Linux distributors. All three actively promote CGL specifications. However, they lack the capability to build platform for other companies to develop their products on.

The relationships of alliance and financial connection, which were not illustrated in Value Net framework, may have important implications

The relationships between the players were more complex than the relationships described in Value Net framework. Four types of relationships were described in Value Net framework: the relationship between the focal players with its customers, suppliers, competitors and complementors. A player in CGL ecosystem established partnership with its customers, suppliers, complementors and even competitors. The networks of partnerships, which illustrate alliance and financial investments, have important implications for companies' influence in the ecosystem. 


\subsection{Discussion of results}

The objective of this research was to use theory to examine publicly available information on companies that are members of the CGL Working Group for the purpose of answering three questions and generate insights. The research questions were:

1. What motivates companies to incorporate CGL specifications into their market offers?

2. How do companies that incorporate CGL specifications into their products create and appropriate value?

3. What roles do specific companies play in the business ecosystem anchored around the CGL Working Group initiative?

Three motivations of companies to participate in open source projects were not supported by the data in this research: (i) enable users to innovate, (ii) access skilled personnel, and (iii) intrinsic community based incentives. In the case of CGL, companies adopted CGL specifications for commercial or market considerations. Instead of taking advantages of the contributions from individuals, companies tried to contribute to the CGL Working Group and kept better alignment with the CGL specifications.

This research was able to identify specific actions carried out by companies that were deemed by the researcher to create and appropriate value from an open source platform. Previous studies describe abstract strategies to create and appropriate value. To increase the number of users of CGL products, companies in the CGL Working Group introduced new CGL products or incorporated CGL specifications in existing products. Linux 
distributors like MontaVista, Red Hat and Wind River provided CGL compliant Linux distributions for their customers. Intel, IBM, Sun and HP added CGL operating system as an option on their servers. Ericsson and NTT used CGL platforms in their products and/or infrastructures.

To increase customers' willingness to pay for CGL products, companies in the CGL Working Group contributed to CGL projects to make CGL offers more attractive to customers. These companies released proprietary code as open source to the CGL initiative and invested in CGL projects.

Intel and IBM released blade server specifications. These specifications facilitate the applications of CGL in blade servers. Wind River and Ericsson opened Transparent InterProcess Communication (TIPC) protocol, which provided portability of code between Linux and the VxWorks operating system. Ericsson released the code of Linux kernel module- DigSig. Intel, IBM, HP, MontaVista and NTT invested in CGL related projects. Only Sun and Red Hat did not make contributions to the CGL Working Group.

The companies in the CGL Working Group established partnerships with customers and complementors to decrease buyers' costs and increase buyers' willingness to pay for CGL products. All the companies in the sample had established networks with their customers and complementors. 
To decrease costs of providing CGL products, companies in the CGL Working Group reduced their costs of offering CGL related products. NTT used a standards platform to reduce its operating cost and simplify its maintenance process. Ericsson developed components and building blocks to expedite development and decrease development costs.

To appropriate value, companies in the sample carried out three types of actions: (i) increased customers' willingness to pay for the company's products; (ii) decreased buyers' willingness to pay for competitors' products; and (iii) decreased suppliers' cost to provide resources to the company.

To increase customers' willingness to pay for the company's products, companies in the CGL Working Group provided differentiated products by combining their technical strengths with CGL specifications. Intel worked closely with its partner through its Intel Communications Alliance for the purpose of providing Intel-based CGL solutions. Sun ported its Java Enterprise System on Linux and supported CGL stack on UltraSPARC T1 platform. HP supported Debian CGL distribution to speed customers' deployment of services and reduce costs. IBM released the specifications of its blade server running CGL operating system, which brought openness to its products and attract complements suppliers. MontaVista's Carrier Grade Edition, a CGL compliant product, was the first product fully compliant with CGL and the first one getting dual registration from CGL and SA Forum. Wind River offered the CGL platform that was compatible with its VxWorks operating system. Red Hat worked closely with partners of its 
Telecommunications Partner Program to provide closer alignment with CGL requirements than other Linux providers. Ericsson simplifies its development process and reduces cost of development to benefit customers also benefit with high-quality, carrier grade products. NTT adopted Linux to build a unifying and open platform for its infrastructure, which makes deployment of applications much quicker.

Companies in the CGL Working Group established partnerships with companies that were not members of the CGL Working Group but provide complementary products and services for CGL products. These partnerships included Intel Communications Alliance, IBM's PartnerWorld Telecommunications Industry Network and Red Hat's Telecommunications Partner Program.

Companies in the CGL Working Group provided migration programs for competitors' products. Sun created campaign to replace Red Hat in favor of Solaris. HP provided programs to help Sun's customers move from Solaris to HPUX or Linux. IBM initiated a program helping customers migrate from Sun to Linux. Red Hat launched trade-in program for companies using MontaVista Linux.

To decrease buyers' willingness to pay for competitors' products, HP supported Debian, a free CGL distribution. This action could reduce other commercial CGL distributor's value.

To decrease suppliers' cost to provide resources to the company, the companies in the 
CGL Working Group established partnerships with suppliers to strength the connections with suppliers and facilitate the transactions. In this research, Linux distributors did not have suppliers.

This research highlights the importance of developing open source platforms in general and CGL specifically. The CGL initiative stands at the centre of the move from proprietary to open platforms in the telecommunications industry.

Setting criteria to identify company roles in an ecosystem proved to be a difficult undertaking. Research in this area is just starting. This research uses metrics from networking theory in an attempt to define company roles in the GCL ecosystem.

This research suggests that multiple keystone companies may co exist in one ecosystem. The perspective held in the cases examined in the literature is that only one keystone company exists in an ecosystem. 


\section{CONCLUSIONS}

\subsection{Conclusions}

This research answers three questions: (i) what motivates companies to incorporate CGL specifications into their products, (ii) how these companies create and appropriate value, and (iii) what roles these companies play in the ecosystem anchored around the CGL Working Group initiative. To answer the questions, two theoretical perspectives were used to examine publicly available information on nine companies.

\subsection{Limitations}

The data in this research was collected from secondary sources such as companies' news releases, annual reports, and independent analysts' reports. This research did not interview company managers. Thus, this research suffers the limitations of all research that uses secondary sources of information. Some possible motivations may not be identified due to the limitation of data collection. For instance, companies that had conflicting interests with CGL initiative may participate in the CGL Working Group to disturb the development of CGL specifications.

Due to lack of data availability, middleware, application and service providers were excluded from this research. These companies are comparably small companies and rely on the big players inside CGL ecosystem; and their motivations and strategies may different from the selected companies in this research. 


\subsection{Future research}

Three suggestions for future research are suggested.

First, other open source platforms can be examined to validate the results obtained in this research study. This research is a start point to examine the business ecosystems anchored around open source platforms. The keystone strategies were useful but not decisive in identifying the roles of the companies in an ecosystem anchored around open source platform. More researches can be done to expand this theory in specific domains.

Second, other theoretical perspectives can be used to open source platforms.

For instance, the landscape theory of aggregation and the theory of multisided platform can enrich the research through different perspectives. Using quantitative measures to examine open source platform may lead to more concrete statements for the strategies of value creation and appropriation.

Third, the relationships among keystone companies and the CGL Working Group should be examined. The finding that there more than one keystone company exists is an important one. This raises questions such as: how do keystone companies relate to one another? How do keystone companies relate to the open platform?

Fourth, the theory of value creation and appropriation seems to better apply to the study of an open platform than to the study of a keystone company. The value creation- 
appropriation perspective can be used to identify the differences between these two situations. 


\section{REFERENCES}

Bowmam, C. \& Ambrosini, V. 2000. Value creation versus value capture: Towards a coherent definition of value in strategy. British Journal of Management, 11: 1-15.

Brandenburger, A.M. \& Nalebuff, B.J. 1996. Co-opetition. New York: Harper Collins.

Brandenburger, A.M. \& Stuart, H.W. 1996. Value-based strategy. Journal of Economics \& Management Strategy, 5:5-24.

Curiel, I. 1997. Cooperative Game Theory and Applications. Kluwer Academic Publishers.

Eisenhardt, K. M. 1989. Building theories from case study research. Academy of Management Review, 14(4):532-550.

Evans, D. S., Hagiu, A. \& Schmalensee, R. 2006. Invisible Engines: How Software Platforms Drive Innovation and Transform Industries. Cambridge, MA: MIT Press.

Feller, J., et al. 2005. Perspectives on Free and Open Source Software. Cambridge, MA: MIT Press.

Feller J. \& Fitzgerald B. 2002. Understanding Open Source Software Development. Boston, MA, Addison Wesley.

Fink, M. 2003. The Business and Economics of Linux and Open source. Upper Saddle River, NJ, Prentience Hall.

Gabriel, R. P. \& Goldman, R. 2005. Innovation Happens Elsewhere. Morgan Kaufmann 
Publishers.

Gans, J. S., MacDonald, G. \& Ryall, M.D. 2006. Operationalizing value-based business strategy. http://www.olin.wustl.edu/faculty/macdonald/Operationalizing.pdf

Ghosh, R. A. 2006. Study on the: Economic impact of open source software on innovation and the competitiveness of the Information and Communication Technologies (ICT) sector in the EU . http://ec.europa.eu/enterprise/ict/policy/doc/2006-11-20-flossimpact.pdf

Guo, X. 2003. Base On the Theory of Ecosystem-the Study of Business Ecosystem. Guangzhou (China): Jinan University.

Haddad, I. 2006. Carrier Grade Linux in mobile infrastructures: Requirements, market trends, deployments and challenges. Wireles \& Mobile Expo and Conference. http://doc.wowgao.com/RFID/wm06/presentations/lbrahimHaddad.pdf

Hansmann, H. 1996. The Ownership of Enterprise. Cambridge, MA: The Belknap Press of Harvard University Press.

Hawkins, R.E. 2004. The economics of open source software for a competitive firm: why give it free? Netnomics, 6: 103-117.

Hecker, F. 1999. Setting up shop: The business of open-source software. IEEE Software, $16(1): 45-51$.

Henkel, J. 2003. Open source software from commercial firms - Tools, complements, and collective invention. http://www.inno-tec.bwl.unimuenchen.de/forschung/henkel/OSS JHenkel 2003-05.pdf. 
Henkel, J. 2004. Patterns of free revealing - balancing code sharing and protection in commercial open source development. http://opensource.mit.edu/papers/henkel2.pdf

Iansiti, M. \& Levien, R. 2004. The Keystone Advantage: What the New Dynamics of Business Ecosystems Mean for Strategy, Innovation, and Sustainability. Harward Business School Press.

Iyer, B., Lee, C., \& Venkatraman, N. 2006. Managing in a small world ecosystem: lessons from the software sector. California Management Review, 48(3): 28-47.

Katz, M. \& Shapiro, C. 1985. Network externalities, competition and compatibility. American Economic Review, 75: 424 440.

Katz, M. \& Shapiro, C. 1992. Product introduction with network externalities. Journal of Industrial Economics, 40(1): 55-84.

Koeing, J. 2004. Seven open source business strategies for competitive advantage. IT Manager's Journal, May 14.

Lerner, J. \& Tirole, J. 2001. The Open Source Movement: Key Research Questions. European Economic Review, 45: 819-826.

Lerner, J. \& Tirole, J. 2002a. Some simple economics of open source. The Journal of Industrial Economics, 50: 197-234.

Lerner, J. \& Tirole, J. 2002b. The Scope of Open Source Licensing. http://www.people.hbs.edu/jlerner/OSLicense.pdf.

Liu, X. 2006. Assessing the release of proprietary code as open source: large company 
case. Carleton University TIM thesis, Ottawa, Canada.

MacDonald, G. \& Ryall, M.D. 2004. How do value creation and competitive determine whether a firm appropriates value? Management Science, 50: 1319-1333.

Moore, J.F. 1993. Predators and Prey: The New Ecology of Competition. Harward Business Review, 71(3): 75-83.

Moore, J.F. 1996. The Death of Competition: Leadership \& Strategy in the Age of Business Ecosystems. New York, Harper Business.

Peltoniemi, M. \& Vuori, E. 2004. Business ecosystem as the new approach to complex adaptive business environments. Proceedings of eBusiness Research Forum, Tampere.

Raymond, E. S. 1999a. The Cathedral and the Bazaar: Musings on Linux and Open Source by an Accidental Revolutionary. CA: O'Reilly.

Raymond, E.S. 1999b. The Magic Cauldron. http://www.catb.org/ esr/writings/magiccauldron/magic-cauldron.html

Rogers, E. 2003. Diffusion of Innovations. New York:Free Press.

Rossi, C. \& Bonaccorsi, A. 2004a. Intrinsic motivations and profit-oriented firms in open source software. Do firms practice what they preach?

http://freesoftware.mit.edu/papers/rossi_motivations.pdf

Rossi, C. \& Bonaccorsi, A. 2004b. Comparing motivations of individual programmers and firms to take part in the open source movement. From community to business. http://opensource.mit.edu/papers/bnaccorsirossimotivationlong.pdf 
Shapiro, C. \& Varian, H. R. 1999. The art of standard wars. California Management Review, 41(2): 8-32.

Suarez, F. 2005. Network effects revised: the role of strong ties in technology selection. The Academy of Management Journal. 48(4): 710 - 720.

Tuma D. 2005. Open Source Software: Opportunities and Challenges. CrossTalk. The Journal of Defense Software Engineering, January Issue.

http://www.stsc.hill.af.mil/crosstalk/2005/01/0501Tuma.html

Venkatraman, N., Lee, C. H. \& Iyer, B. 2004. Make way for the penguin? Explaining commitment to Linux by software companies. Paper presented at the annual meeting of the Academy of Management, New Orleans.

von Hippel, E. 2002. Open source projects as horizontal innovation networks - by and for users. SSRN Working paper, http://papers.ssrn.com/sol3/delivery.cfm/SSRN ID328900_code020906590.pdf?abstracti $\mathrm{d}=328900$.

von Hippel, E. \& von Krogh, G. 2003. Open source software and the "private-collective" innovation model: Issues for organization science. Organization Science, 14(2): 209-223. von Krogh, G., Spaeth, S. \& Lakhani, K. 2003. Community, joining, and specialization in open source software innovation: A case study. Research Policy, 32(7): 1217-1241.

Yin, R. 1994. Case study research: Design and methods. Beverly Hills, CA: Sage Publishing. 
Yin, R. 2003. Applications of case study research. Beverly Hills, CA: Sage Publications.

Weinberg, B. 2005. Carrier Grade Linux 3.0: Building out and looking forward.

Embedded Computing Design, May 2005.

West, J. 2003. How open is open enough? Melding proprietary and open source platform strategies. Research Policy, 32: 1259-1285

West, J. \& Gallagher, S. 2004. Key challenges of open innovation: Lessons from open source software. Working paper.

http://www.cob.sjsu.edu/west j/Papers/WestGallagher2004.pdf.

Wichmann, T. 2002a. Firms' Open Source activities: motivations and policy implications. Free/Libre and Open Source Software: Survey and Study, FLOSS Final Report, International Institute of Infonomics, Berlecom Research GmbH. http://www.berlecon.de/studien/downloads/200207FLOSS Activities.pdf

Wichmann T. 2002b. Use of Open Source Software in Firms and Public Institutions. Evidence from Germany, Sweden and UK. Free/Libre and Open Source Software: Survey and Study, FLOSS Final Report, International Institute of Infonomics, Berlecom Research GmbH. 


\section{Appendix A: Carrier Grade Linux}

CGL (Carrier Grade Linux) was formed in 2002 as one of the Working Groups of OSDL.

The CGL Working Group is an initiative designed to accelerate the adoption of Linux in the telecommunications industry. The member companies of the CGL Working Group include network equipment providers, system integrators, hardware platform providers, Linux distributors, service providers, middleware and applications providers, and carriers. These companies work together to collect, define and prioritize requirements that enhance the standard Linux operating system so as to work in demanding carrier environments.

The major tasks of the CGL Working Group include identifying requirements, developing specification, broadening industry support of CGL, and enhancing the value of open, industry standard building blocks.

(http://www.linux-foundation.org/en/About_the_CGL_Workgroup)

CGL Working Group is one of the building blocks of standard based network element, which is illustrated in Figure 10.

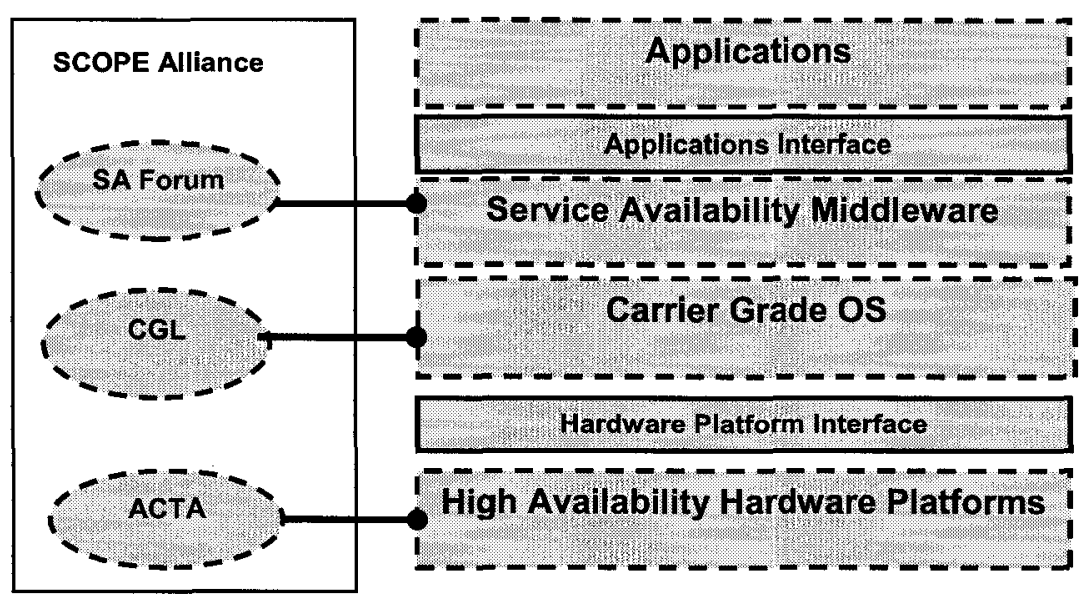

Figure 1: Standards based network elements 
Appendix B: Members of CGL Working Group as of May 2005

\begin{tabular}{|c|c|c|}
\hline & Companies & $\begin{array}{l}\text { Selected cases for this } \\
\text { research }\end{array}$ \\
\hline Silicon provider & Intel & Intel \\
\hline Linux provider & $\begin{array}{l}\text { MontaVista, Wind River, Red Hat, Novell, } \\
\text { TurboLinux, TimeSys, LynuxWorks }\end{array}$ & $\begin{array}{l}\text { MontaVista } \\
\text { Wind River } \\
\text { Red Hat }\end{array}$ \\
\hline System supplier & IBM, HP, Sun & IBM, HP, Sun \\
\hline $\begin{array}{l}\text { Network equipment } \\
\text { supplier }\end{array}$ & $\begin{array}{l}\text { Nokia, Ericsson, Alcatel, Fujitsu, Hitachi, Cisco, } \\
\text { NEC }\end{array}$ & Ericsson \\
\hline Carrier & NTT, NTT Data Intellilink & NTT \\
\hline $\begin{array}{l}\text { Integration and } \\
\text { service provider }\end{array}$ & SISO & \\
\hline $\begin{array}{l}\text { Middleware and } \\
\text { application } \\
\text { providers }\end{array}$ & Comverse, BakBone, Aduva & \\
\hline
\end{tabular}




\section{Appendix C: Company information}

\begin{tabular}{|c|c|c|c|c|}
\hline & Core business & Products and Services & CGL related products & Revenue \\
\hline Intel & $\begin{array}{l}\text { Silicon Provider } \\
\text { System Supplier }\end{array}$ & $\begin{array}{l}\text { - Microprocessors, chipsets \& } \\
\text { motherboards } \\
\text { - Flash memory } \\
\text { - LAN, WLAN, WiMax } \\
\text { - Network processors and optical } \\
\text { components }\end{array}$ & $\begin{array}{l}\text { - Carrier grade rack mount } \\
\text { servers (RMS) }\end{array}$ & $\begin{array}{l}38.8 \text { billion USD } \\
(2005)\end{array}$ \\
\hline Sun & $\begin{array}{l}\text { Silicon Provider } \\
\text { System Supplier }\end{array}$ & $\begin{array}{l}\text { - Computer servers } \\
\text { - Workstations } \\
\text { - Storage } \\
\text { - Software } \\
\text { - Services }\end{array}$ & - Netra ATCA blade platform & $\begin{array}{l}13 \text { billion USD } \\
(06 / 30 / 06)\end{array}$ \\
\hline $\mathrm{HP}$ & System Supplier & $\begin{array}{l}\text { - Technology Solutions: Enterprise } \\
\text { Storage and Servers, Services and } \\
\text { Software } \\
\text { - Personal computer system } \\
\text { - Imaging and Printing }\end{array}$ & $\begin{array}{l}\text { ProLiant and BladeSystem } \\
\text { servers }\end{array}$ & $\begin{array}{l}86.7 \text { billion USD } \\
(2005)\end{array}$ \\
\hline IBM & System Supplier & $\begin{array}{l}\text { - Systems } \\
\text { - Financing } \\
\text { - Software } \\
\text { - Services }\end{array}$ & - Blade server: BladeCenter T & $\begin{array}{l}91 \text { billion USD (2005) } \\
2005 \text { IBM \#1 in } \\
\text { Worldwide Server } \\
\text { Revenue, \#1 in UNIX } \\
\text { Server Revenue }\end{array}$ \\
\hline Monta-Vista & Linux Distributor & $\begin{array}{l}\text { - Linux operating system for embedded, } \\
\text { telecom, mobile }\end{array}$ & $\begin{array}{l}\text { - Linux Carrier Grade Edition } \\
\text { (CGE) }\end{array}$ & 15.5 million USD (est.) \\
\hline Wind River & $\begin{array}{l}\text { Device Software } \\
\text { Optimization } \\
\text { platform provider } \\
\text { Linux Distributor }\end{array}$ & $\begin{array}{l}\text { Development platforms based on } \\
\text { VxWorks and Linux OS for network, } \\
\text { medical, automobile, aerospace }\end{array}$ & $\begin{array}{l}\text { - Platform for Network } \\
\text { Equipment, Linux Edition. }\end{array}$ & $\begin{array}{l}\text { 266. } 323 \text { million USD } \\
(2005)\end{array}$ \\
\hline
\end{tabular}




\begin{tabular}{|c|c|c|c|c|}
\hline Red Hat & Linux Distributor & $\begin{array}{l}\text { - Red Hat Enterprise Linux } \\
\text { - Red Hat Desktop Linux }\end{array}$ & - Red Hat Enterprise Linux & $\begin{array}{l}278.3 \text { million USD } \\
(02 / 28 / 06)\end{array}$ \\
\hline Ericsson & $\begin{array}{l}\text { Telecom } \\
\text { Equipment } \\
\text { Manufacture }\end{array}$ & $\begin{array}{l}\text { - Systems (mobile and fixed line telecom } \\
\text { network) } \\
\text { - Phones (mobile handsets) } \\
\text { - Microwave Systems (Defense) } \\
\text { - Enterprise Systems } \\
\text { - Network Technologies (Cables) } \\
\text { - Mobile Platforms } \\
\text { - Power Modules }\end{array}$ & $\begin{array}{l}\text { - Integrated Site and Telecom } \\
\text { Server Platform }\end{array}$ & 22.3 billion USD (2005) \\
\hline NTT & Telecom Carrier & - Telecom service & $\begin{array}{l}\text { - Telecom service infrastructure } \\
\text { incorporate CGL products }\end{array}$ & $\begin{array}{l}90.76 \text { billion USD } \\
\text { (March } 31,2006 \text { ) }\end{array}$ \\
\hline
\end{tabular}




\section{Appendix C: Company information (Continued)}

\begin{tabular}{|c|c|c|c|}
\hline & Involved open source projects & products for telecommunications & participated technical alliances \\
\hline Intel & $\begin{array}{l}\text { OS projects: } \\
\text { - ACPI } \\
\text { - OpenHPI } \\
\text { - Intel PRO/Wireless Driver for Linux } \\
\text { - Linux graphics drivers }\end{array}$ & $\begin{array}{l}\text { - Server blade } \\
\text { - WiMAX } \\
\text { - Network processors } \\
\text { - Optical components }\end{array}$ & $\begin{array}{l}\text { - Advanced Telecom Computing } \\
\text { Architecture (ATCA) } \\
\text { - Service Availability (SA) Forum } \\
\text { - OSDL Mobile Linux Initiative }\end{array}$ \\
\hline Sun & $\begin{array}{l}\text { - OpenSolaris } \\
\text { - OpenOffice } \\
\text { - GNOME } \\
\text { - NetBeans, }\end{array}$ & $\begin{array}{l}\text { - Servers } \\
\text { - Storage } \\
\text { - Software } \\
\text { - Services }\end{array}$ & $\begin{array}{l}\text { - Advanced Telecom Computing } \\
\text { Architecture (ATCA) } \\
\text { - Communications Platforms } \\
\text { Trade Association (CP-TA) } \\
\text { - Service Availability (SA) Forum } \\
\text { - SCOPE Alliance }\end{array}$ \\
\hline HP & $\begin{array}{l}\text { OS is used in: } \\
\text { - Embedded } \\
\text { - Desktop } \\
\text { - Tools\&procedures }\end{array}$ & $\begin{array}{l}\text { - Blade Server } \\
\text { - Rack-mount servers } \\
\text { - OpenCall Custom Telecom Solutions } \\
\text { - HP OpenView Management } \\
\text { - IP Multimedia Subsystem (IMS) }\end{array}$ & $\begin{array}{l}\text { - Advanced Telecom Computing } \\
\text { Architecture (ATCA) } \\
\text { - Communications Platforms } \\
\text { Trade Association (CP-TA) } \\
\text { - Service Availability (SA) Forum }\end{array}$ \\
\hline IBM & $\begin{array}{l}\text { OS strategies for: } \\
\text { - Middleware } \\
\text { - Tools }\end{array}$ & $\begin{array}{l}\text { - BladeCenter T } \\
\text { - Open Integrated Platform for Telecom } \\
\text { - WebSphere Business Integration for } \\
\text { Telecom } \\
\text { - Public Wireless LAN Solution }\end{array}$ & - Service Availability (SA) Forum \\
\hline MontaVista & $\begin{array}{l}\text { Other Linux based products: } \\
\text { - Professional Edition for embedded } \\
\text { devices } \\
\text { - Consumer Electronics Edition } \\
\text { - Mobolinux for mobile devices }\end{array}$ & & $\begin{array}{l}\text { - Communications Platforms } \\
\text { Trade Association (CP-TA) } \\
\text { - OSDL Mobile Linux Initiative } \\
\text { - Service Availability (SA) Forum }\end{array}$ \\
\hline
\end{tabular}




\begin{tabular}{|c|c|c|c|}
\hline Wind River & $\begin{array}{l}\text { - Strategic member of Eclipse } \\
\text { - Linux product for other industry }\end{array}$ & $\begin{array}{l}\text { - Wind River Platform for Networking } \\
\text { Equipment, VxWorks Edition }\end{array}$ & $\begin{array}{l}\text { - Communications Platforms } \\
\text { Trade Association (CP-TA) } \\
\text { - OSDL Mobile Linux Initiative } \\
\text { - Service Availability (SA) Forum } \\
\text { - Mountain View Alliance } \\
\text { - SCOPE Alliance }\end{array}$ \\
\hline Red Hat & $\begin{array}{l}\text { - Red Hat Enterprise Linux } \\
\text { - Red Hat Desktop Linux } \\
\text { - JBoss middleware }\end{array}$ & & \\
\hline Ericsson & $\begin{array}{l}\text { - Linux Group to Centralize Linux } \\
\text { handling }\end{array}$ & & $\begin{array}{l}\text { - SCOPE Alliance } \\
\text { - Service Availability (SA) Forum }\end{array}$ \\
\hline NTT & $\begin{array}{l}\text { - Data Center Linux Initiative } \\
\text { - Mobile Linux Initiative. }\end{array}$ & & $\begin{array}{l}\text { - Service Availability (SA) Forum } \\
\text { - Mobile device platform } \\
\text { foundation }\end{array}$ \\
\hline
\end{tabular}


Appendix D: Motivations for companies to incorporate CGL specifications into their products

\begin{tabular}{|c|c|c|c|c|c|}
\hline & $\begin{array}{l}\text { 1. Eliminate suppliers' } \\
\text { lock-in }\end{array}$ & $\begin{array}{l}\text { 2. Sell complimentary } \\
\text { products and services }\end{array}$ & $\begin{array}{l}\text { 3. Enable users to } \\
\text { innovate }\end{array}$ & $\begin{array}{l}\text { 4. Access skilled } \\
\text { personnel }\end{array}$ & $\begin{array}{l}\text { 5. Reduce } \\
\text { company's } \\
\text { development or } \\
\text { operating costs }\end{array}$ \\
\hline Intel & & $\begin{array}{l}\text { Sell CPUs, boards, severs } \\
\text { supporting CGL. }\end{array}$ & & & \\
\hline Sun & & Sell severs installing CGL. & & & \\
\hline HP & & Sell severs installing CGL. & & & \\
\hline IBM & $\begin{array}{l}\text { Use CGL to enable } \\
\text { customers to easily migrate } \\
\text { from Intel platforms to } \\
\text { IBM's mainframes } \\
\text { reducing customers' } \\
\text { dependency on Intel. }\end{array}$ & Sell severs installing CGL. & & & \\
\hline MontaVista & & $\begin{array}{l}\text { Get revenue by } \\
\text { subscription or service for } \\
\text { CGL. }\end{array}$ & & & \\
\hline Wind River & & $\begin{array}{l}\text { Get revenue by } \\
\text { subscription or service for } \\
\text { CGL. } \\
\text { Sell the CGL open } \\
\text { platform as a complement }\end{array}$ & & & \\
\hline
\end{tabular}




\begin{tabular}{|c|c|c|c|}
\hline & & $\begin{array}{l}\text { for its established } \\
\text { VxWorks product line. }\end{array}$ & \\
\hline Red Hat & & $\begin{array}{l}\text { Get revenue by } \\
\text { subscription or service for } \\
\text { CGL. }\end{array}$ & \\
\hline Ericsson & & & $\begin{array}{l}\text { Ericsson uses Linux } \\
\text { building blocks to } \\
\text { decrease its cost of } \\
\text { developin } \\
\text { telecommunications } \\
\text { products. The } \\
\text { Common Processor } \\
\text { Board Subsystem } \\
\text { (CPBS), a combined } \\
\text { hardware and } \\
\text { software solution for } \\
\text { developing } \\
\text { Integrated Site } \\
\text { application blades, } \\
\text { is one of the } \\
\text { building blocks. By } \\
\text { using open source } \\
\text { components, } \\
\text { Ericsson reduces } \\
\text { costs and attains } \\
\text { shorter development } \\
\text { cycles. }\end{array}$ \\
\hline NTT & $\begin{array}{l}\text { Use CGL in the telecom } \\
\text { market to reduce supplier } \\
\text { dependence. }\end{array}$ & & $\begin{array}{l}\text { NTT uses CGL to } \\
\text { reduce its } \\
\text { development costs. }\end{array}$ \\
\hline
\end{tabular}


Appendix D: Motivations for companies to incorporate CGL specifications into their products (Continued)

\begin{tabular}{|c|c|c|c|c|c|}
\hline & 6. Enter a new market & $\begin{array}{l}\text { 7. Increase market } \\
\text { share }\end{array}$ & $\begin{array}{l}\text { 8. Intrinsic } \\
\text { community based }\end{array}$ & $\begin{array}{l}\text { 9. Increase value for } \\
\text { customers }\end{array}$ & $\begin{array}{l}\text { 10. Introduce } \\
\text { differentiated } \\
\text { products }\end{array}$ \\
\hline Intel & $\begin{array}{l}\text { As part of its plan to make } \\
\text { the transition from being a } \\
\text { PC-centric chip maker to } \\
\text { becoming a versatile } \\
\text { information technology } \\
\text { company, Intel is shaping } \\
\text { its new standard platform } \\
\text { based on Intel architecture } \\
\text { and Linux to take the high- } \\
\text { end server market in the } \\
\text { telecommunications } \\
\text { industry away from Sun. }\end{array}$ & & & $\begin{array}{l}\text { Intel is actively involved in } \\
\text { telecommunications } \\
\text { standardization initiatives } \\
\text { to lower its customers' } \\
\text { costs and improve their } \\
\text { scalability }\end{array}$ & \\
\hline \multicolumn{6}{|l|}{ Sun } \\
\hline HP & & $\begin{array}{l}\text { HP provides the Linux } \\
\text { option in its carrier } \\
\text { grade servers and } \\
\text { blade severs to its } \\
\text { telecommunications } \\
\text { customers. CGL is } \\
\text { part of HP's approach } \\
\text { to take market share } \\
\text { away from IBM in } \\
\text { Blade Server market } \\
\text { market. }\end{array}$ & & $\begin{array}{l}\text { HP's customers are } \\
\text { interested in seeing Linux } \\
\text { on HP's server. HP admits } \\
\text { that it had Debian } \\
\text { registered with CGL } \\
\text { because of their customers' } \\
\text { pull to see the official CGL } \\
\text { registration. }\end{array}$ & \\
\hline
\end{tabular}




\begin{tabular}{|c|c|c|c|c|}
\hline IBM & & $\begin{array}{l}\text { IBM's BladeCenter T } \\
\text { server is built upon } \\
\text { CGL and Intel cores } \\
\text { and specifically } \\
\text { designed to meet the } \\
\text { stringent requirements } \\
\text { of telecom industry. } \\
\text { The IBM server is part } \\
\text { of the company's } \\
\text { strategy to take away } \\
\text { business from Sun, } \\
\text { whose servers used to } \\
\text { dominate the } \\
\text { telecommunications } \\
\text { industry. }\end{array}$ & $\begin{array}{l}\text { IBM provides blade server } \\
\text { based on Linux to reduce } \\
\text { the costs of telecom } \\
\text { industry. }\end{array}$ & \\
\hline MontaVista & $\begin{array}{l}\text { To expand the market for } \\
\text { its Linux distributions, } \\
\text { MontaVista has entered the } \\
\text { telecommunications } \\
\text { market by working closely } \\
\text { with the leading telecom } \\
\text { equipment makers in } \\
\text { defining the CGL } \\
\text { specifications and now } \\
\text { provides CGL compliant } \\
\text { products for its customers. }\end{array}$ & & $\begin{array}{l}\text { MontaVista Linux Carrier } \\
\text { Grade Edition (CGE) } \\
\text { delivers the performance, } \\
\text { flexibility and cost- } \\
\text { efficiency that are required } \\
\text { by telecommunications } \\
\text { equipment manufactures to } \\
\text { for the purpose of } \\
\text { consolidating the } \\
\text { telecommunication } \\
\text { infrastructure. }\end{array}$ & $\begin{array}{l}\text { MontaVista is the } \\
\text { first Linux } \\
\text { distributor who } \\
\text { achieved dual } \\
\text { registration from } \\
\text { both CGL and the } \\
\text { Service } \\
\text { Availability } \\
\text { Forum. By } \\
\text { promptly } \\
\text { delivering CGL- } \\
\text { compliant } \\
\text { products, } \\
\text { MontaVista } \\
\text { strengthened its } \\
\text { position in the } \\
\text { telecommunication } \\
\text { market. }\end{array}$ \\
\hline
\end{tabular}




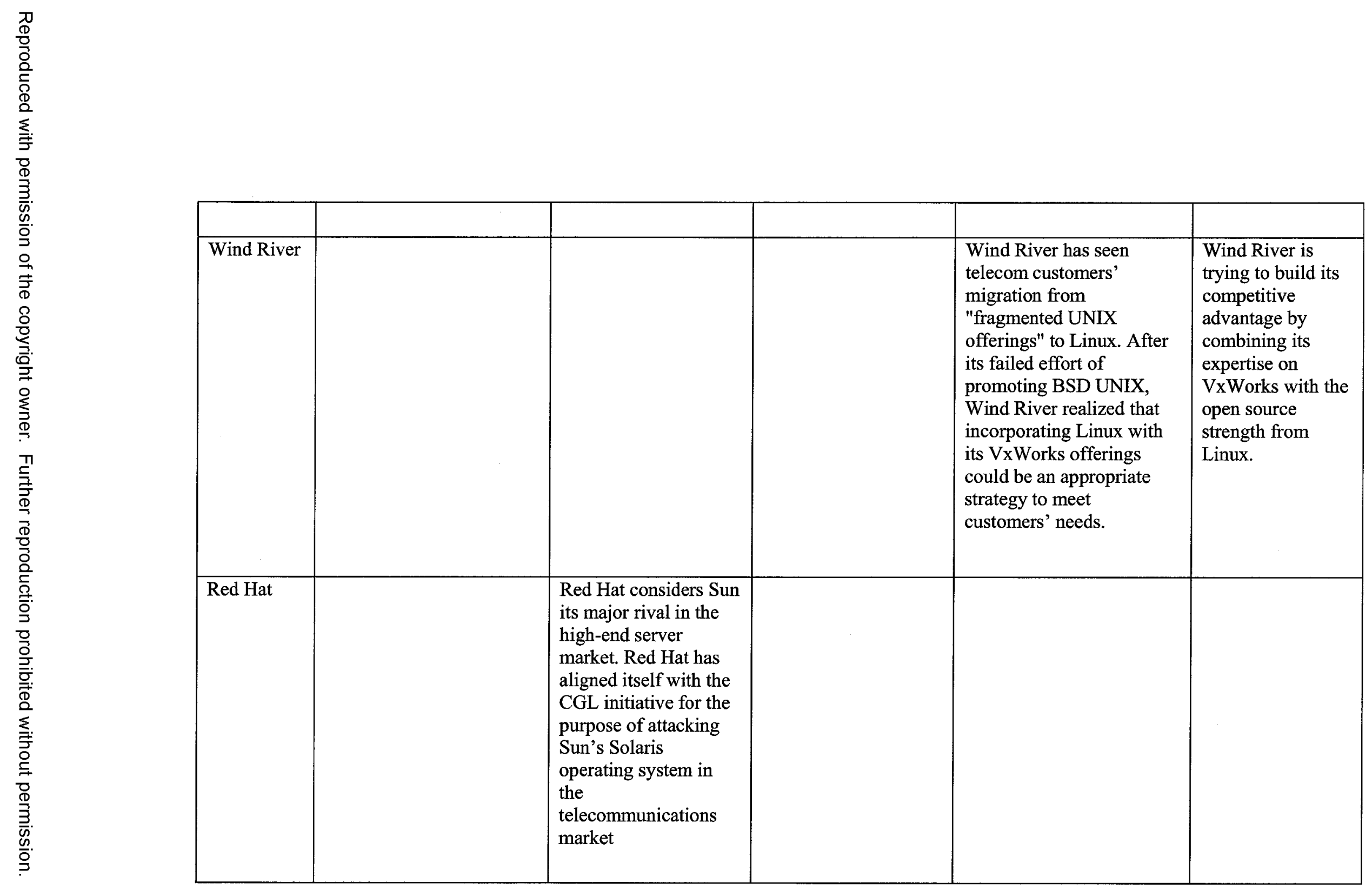




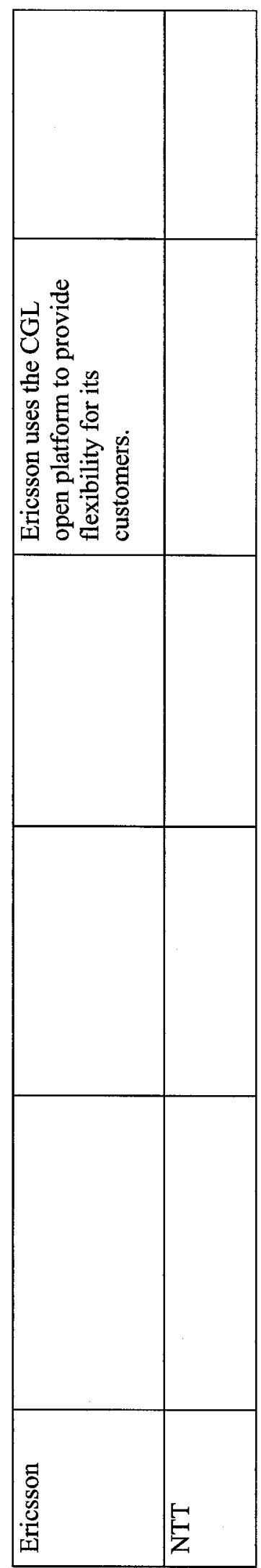

Reproduced with permission of the copyright owner. Further reproduction prohibited without permission. 
Appendix E: Actions carried out to create value from CGL initiative

\begin{tabular}{|c|c|c|c|c|}
\hline & $\begin{array}{l}\text { 1. } \\
\text { Actions to increase the number } \\
\text { of users of CGL products }\end{array}$ & \multicolumn{2}{|c|}{$\begin{array}{l}2 . \\
\text { Actions to increase customers' willingness to pay for CGL } \\
\text { products }\end{array}$} & \multirow[t]{2}{*}{$\begin{array}{l}\text {. } \\
\text { Actions to decrease } \\
\text { company's development } \\
\text { or operating costs }\end{array}$} \\
\hline & $\begin{array}{l}\text { 1A. } \\
\text { Introduced new CGL products } \\
\text { or incorporated CGL } \\
\text { specifications into existing } \\
\text { products }\end{array}$ & $\begin{array}{l}2 \mathrm{~A} . \\
\text { Released proprietary } \\
\text { code into CGL or } \\
\text { supported CGL projects }\end{array}$ & $\begin{array}{l}\text { 2B. } \\
\text { Established partnerships with } \\
\text { customers and complementors }\end{array}$ & \\
\hline Intel & $\begin{array}{l}\text { - Use CGL in carrier grade rack } \\
\text { mount servers }\end{array}$ & $\begin{array}{l}\text { - Involved in projects: } \\
\text { OpenIPMI, OpenHPI } \\
\text { Open Blade server } \\
\text { specification }\end{array}$ & $\begin{array}{l}\text { - Partner with IBM, HP, Sun, } \\
\text { Cisco, Nokia, Alcatel, Ericsson, } \\
\text { NEC, Hitachi, Fujitsu, NTT, } \\
\text { MontaVista, Red Hat, Wind } \\
\text { River, TimeSys, LynuxWorks, } \\
\text { TurboLinux, Novell, SISO, } \\
\text { BakBone }\end{array}$ & \\
\hline Sun & - Provide CGL compliant servers & & $\begin{array}{l}\text { Partner with IBM, HP, Cisco, } \\
\text { Nokia, Alcatel, Ericsson, NEC, } \\
\text { Hitachi, Fujitsu, NTT, } \\
\text { MontaVista, Red Hat, Wind } \\
\text { River, TimeSys, LynuxWorks, } \\
\text { TurboLinux, Novell, SISO, } \\
\text { BakBone }\end{array}$ & \\
\hline $\mathrm{HP}$ & $\begin{array}{l}\text { - Use CGL in its products like } \\
\text { blade servers }\end{array}$ & $\begin{array}{l}\text { - Support Debian } \\
\text { community }\end{array}$ & $\begin{array}{l}\text { Partner with Intel, IBM, Sun, } \\
\text { Cisco, Nokia, Alcatel, Ericsson, } \\
\text { NEC, Hitachi, NTT, Red Hat, } \\
\text { Novell, LynuxWorks, } \\
\text { TurboLinux, SISO, Comverse, }\end{array}$ & \\
\hline
\end{tabular}




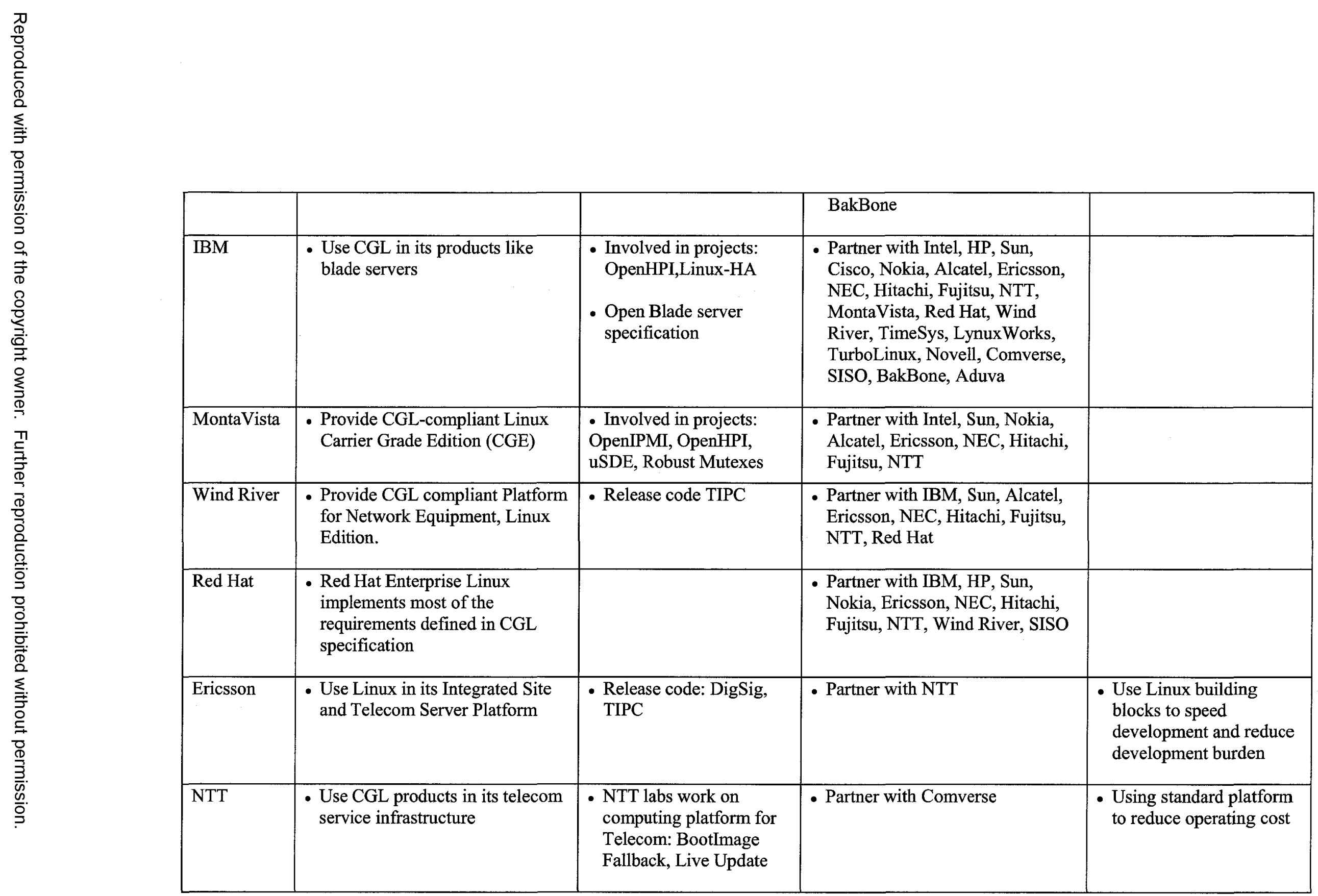


Appendix F: Actions carried out to appropriate value that was created with CGL initiative

\begin{tabular}{|c|c|c|c|c|c|c|}
\hline & \multicolumn{3}{|c|}{$\begin{array}{l}\text { 1. } \\
\text { Actions to increase buyers' willingness to pay for the company's } \\
\text { products }\end{array}$} & $\begin{array}{l}2 . \\
\text { Actions to } \\
\text { decrease } \\
\text { buyers' } \\
\text { willingness to } \\
\text { pay for } \\
\text { competitors' } \\
\text { products }\end{array}$ & $\begin{array}{l}\text { 3. } \\
\text { Actions to } \\
\text { decrease } \\
\text { suppliers' } \\
\text { costs of } \\
\text { providing } \\
\text { resources to } \\
\text { the company }\end{array}$ & \multirow[t]{2}{*}{$\begin{array}{l}4 . \\
\text { Actions to } \\
\text { increase } \\
\text { suppliers' } \\
\text { opportunity } \\
\text { costs to } \\
\text { provide } \\
\text { resources } \\
\text { to } \\
\text { competitors }\end{array}$} \\
\hline & $\begin{array}{l}\text { A. } \\
\text { Provided } \\
\text { differentiated } \\
\text { products }\end{array}$ & $\begin{array}{l}\text { 1B. } \\
\text { Established partnerships } \\
\text { with companies that are } \\
\text { not CGL members but } \\
\text { provide complementary } \\
\text { products to CGL }\end{array}$ & $\begin{array}{l}\text { 1C. } \\
\text { Provided migration } \\
\text { programs for } \\
\text { competitors' } \\
\text { customers }\end{array}$ & $\begin{array}{l}2 A . \\
\text { Provided free } \\
\text { CGL } \\
\text { distribution }\end{array}$ & $\begin{array}{l}2 B . \\
\text { Established } \\
\text { partnership } \\
\text { with suppliers }\end{array}$ & \\
\hline Intel & $\begin{array}{l}\text { Work closely with } \\
\text { partners to provide } \\
\text { Intel-based CGL } \\
\text { solutions on top of } \\
\text { ATCA }\end{array}$ & $\begin{array}{l}\text { - Intel Communications } \\
\text { Alliance }\end{array}$ & & & $\begin{array}{l}\text { Partner with } \\
\text { MontaVista, } \\
\text { Red Hat, } \\
\text { Wind River, } \\
\text { TimeSys, } \\
\text { LynuxWorks, } \\
\text { TurboLinux, } \\
\text { Novell }\end{array}$ & \\
\hline Sun & $\begin{array}{l}\text { - Support CGL stacks } \\
\text { on UltraSPARC T1 } \\
\text { platform } \\
\text { - Port Java Enterprise } \\
\text { System on Linux }\end{array}$ & & $\begin{array}{l}\text { - Create campaign to } \\
\text { replace Red Hat in } \\
\text { favour of Solaris }\end{array}$ & & $\begin{array}{l}\text { - Partner with } \\
\text { MontaVista, } \\
\text { Red Hat, } \\
\text { Wind River, } \\
\text { TimeSys, } \\
\text { LynuxWorks, } \\
\text { TurboLinux, }\end{array}$ & \\
\hline
\end{tabular}




\begin{tabular}{|c|c|c|c|c|c|}
\hline & & & & & Novell \\
\hline $\mathrm{HP}$ & $\begin{array}{l}\text { - Use Debian, HP } \\
\text { benefits its customers } \\
\text { by } \\
\text { 1.deploying services } \\
\text { quickly and less } \\
\text { expensively } \\
\text { 2.providing features not } \\
\text { available by other } \\
\text { Linux distributions } \\
\text { 3.providing true choice } \\
\text { to eliminate vendor } \\
\text { lock-in } \\
\text { 4.supporting real free } \\
\text { Linux (no subscription } \\
\text { fee) }\end{array}$ & & $\begin{array}{l}\text { Provide programs } \\
\text { to help Sun's } \\
\text { customers move } \\
\text { from Solaris to } \\
\text { HPUX or Linux, }\end{array}$ & $\begin{array}{l}\text { - Support } \\
\text { Debian } \\
\text { version of } \\
\text { Linux } \\
\text { distribution, } \\
\text { decrease the } \\
\text { value of other } \\
\text { Linux } \\
\text { distributors }\end{array}$ & $\begin{array}{l}\text { - Partner with } \\
\text { Intel, Red } \\
\text { Hat, Novell, } \\
\text { LynuxWorks, } \\
\text { TurboLinux }\end{array}$ \\
\hline IBM & $\begin{array}{l}\text { - Benefit its customers } \\
\text { by } \\
\text { 1.Releasing } \\
\text { specification of Blade } \\
\text { server } \\
\text { 2.providing } \\
\text { comprehensive products } \\
\text { and solutions }\end{array}$ & $\begin{array}{l}\text { - PartnerWorld } \\
\text { Telecommunications } \\
\text { Industry Network } \\
\text { - BladeServer } \\
\text { - Telecommunications } \\
\text { Solutions Labs (TSLs) }\end{array}$ & $\begin{array}{l}\text { Initiate a program } \\
\text { helping customers } \\
\text { migrate from Sun to } \\
\text { Linux }\end{array}$ & & $\begin{array}{l}\text { Partner with } \\
\text { Intel, } \\
\text { MontaVista, } \\
\text { Red Hat, } \\
\text { Wind River, } \\
\text { TimeSys, } \\
\text { LynuxWorks, } \\
\text { TurboLinux, } \\
\text { Novell }\end{array}$ \\
\hline MontaVista & $\begin{array}{l}\text { - MontaVista's CGE } \\
\text { 1.supports a wide range } \\
\text { of hardware platform } \\
\text { 2.provides unique } \\
\text { features }\end{array}$ & & & & \\
\hline Wind River & $\begin{array}{l}\text { - Wind River Platform } \\
\text { for Network }\end{array}$ & & $\begin{array}{l}\text { - Launche trade-in } \\
\text { program For }\end{array}$ & & \\
\hline
\end{tabular}




\begin{tabular}{|c|c|c|c|c|}
\hline & $\begin{array}{l}\text { Equipment, Linux } \\
\text { Edition is } \\
\text { interoperable with } \\
\text { VxWorks platforms } \\
\text { - Provide } \\
\text { comprehensive } \\
\text { solutions including } \\
\text { development and } \\
\text { runtime products, } \\
\text { Linux-based services } \\
\text { and global product } \\
\text { support }\end{array}$ & & $\begin{array}{l}\text { companies } \\
\text { currently Shipping } \\
\text { devices running } \\
\text { MontaVista Linux }\end{array}$ & \\
\hline Red Hat & $\begin{array}{l}\text { - Red Hat Enterprise } \\
\text { Linux } \\
\text { 1. is compliant with } \\
\text { CGL capability and } \\
\text { 2. provides better } \\
\text { alignment with the } \\
\text { requirement of telecom } \\
\text { industry through Red } \\
\text { Hat's extensive } \\
\text { collaboration with ISVs } \\
\text { and NEPs }\end{array}$ & $\begin{array}{l}\text { - Telecommunications } \\
\text { Partner Program }\end{array}$ & & \\
\hline Ericsson & $\begin{array}{l}\text { - Benefit its customers } \\
\text { by } \\
\text { 1.implementing high- } \\
\text { quality, carrier-grade } \\
\text { products in less time } \\
\text { (shorter time to market) } \\
\text { 2.offering flexible } \\
\text { platform optimized for } \\
\text { operators' requirements } \\
\text { and adjusted to ever- }\end{array}$ & & & $\begin{array}{l}\text { - Partner with } \\
\text { IBM, HP, } \\
\text { Sun, } \\
\text { MontaVista, } \\
\text { Red Hat, } \\
\text { Wind River }\end{array}$ \\
\hline
\end{tabular}




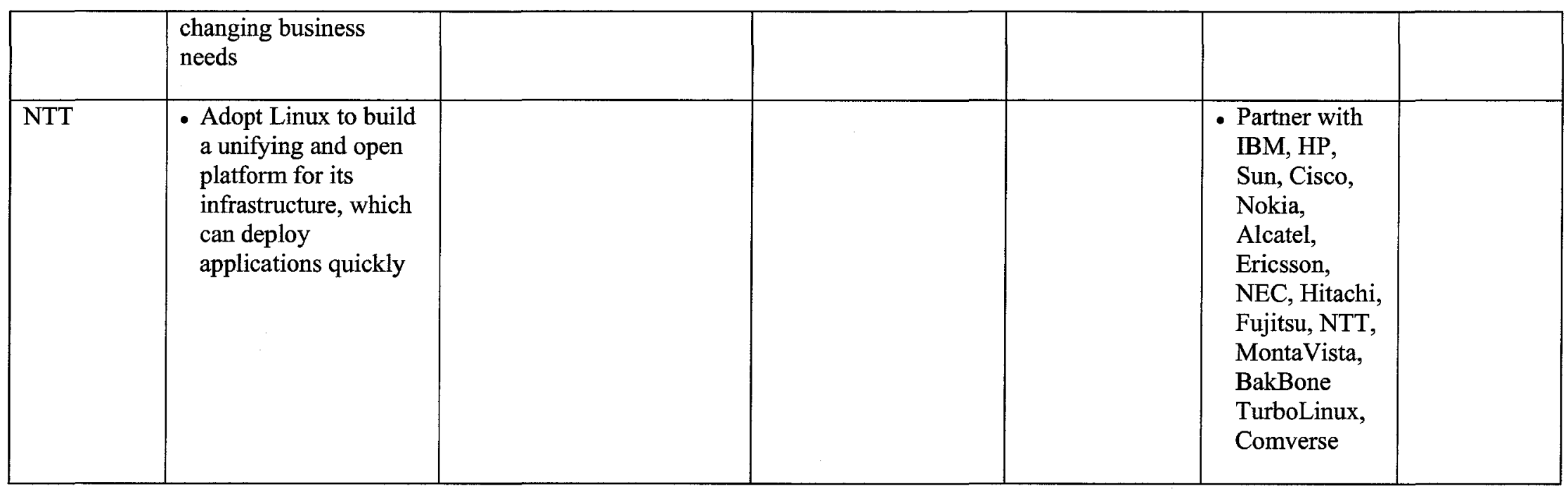




\section{Appendix G: Network of relationships}

\section{Appendix G1: Intel's network of relationships}

Intel established partnership with its customers (IBM, HP, Sun, NTT, Hitachi, NEC, Ericsson, Alcatel, Nokia, Fujitsu, and Cisco), competitors (IBM and Sun) and complementors (TimeSys, LynuxWorks, Wind River and BakBone). Intel also invested in its complementors (Red Hat, TurboLinux, MontaVista, SISO, and Novell).

\begin{tabular}{|c|c|}
\hline Sun & $\begin{array}{l}\text { Intel is a competitor of Intel in processor market with its SPARC architecture. } \\
\text { Sun and Intel formed a strategic alliance centered on Intel's endorsement of the Solaris operating system and Sun's commitment to } \\
\text { deliver a comprehensive family of enterprise and telecom servers and workstations based on Intel Xeon processors (2007). }\end{array}$ \\
\hline HP & Premier member of Intel Communications Alliance. \\
\hline IBM & $\begin{array}{l}\text { IBM and Intel formed blade server alliance. Intel is working with the IBM's Linux for Service Providers Lab to verify and validate } \\
\text { Linux telecom solutions (2003). Although IBM and Intel have close partnership on a range of marketing efforts, IBM's PowerPC } \\
\text { is a competing architecture of Intel's chips. }\end{array}$ \\
\hline MontaVista & MontaVista is an affiliated member of Intel Communications Alliance and got investment from Intel (2000). \\
\hline Novell/SuSE & $\begin{array}{l}\text { Novell worked closely with Intel to optimize SuSE Linux Enterprise for Intel platforms. SuSE's CGL, which SuSE developed } \\
\text { along with HP, IBM and Intel Corp., is initially targeted at Intel-based hardware platforms. Intel also invested in SuSE in } 1999 . \\
\text { Intel is one of Novell's Alliance Partners. }\end{array}$ \\
\hline TurboLinux & Intel is one of the investor of TurboLinux (1999). \\
\hline LynuxWorks & LynuxWorks is an affiliated member of Intel Communications Alliance. \\
\hline
\end{tabular}




\begin{tabular}{|c|c|}
\hline TimeSys & Intel is TimeSys's OnBoard Program members. \\
\hline Red Hat & $\begin{array}{l}\text { Red Hat and Intel created a global program to provide Linux solutions for its customers (2006). Intel took equity stakes in Red Hat } \\
\text { in } 1998 .\end{array}$ \\
\hline BackBone & Intel is one of BakBone's strategic alliance partners. \\
\hline SISO(10art-ni) & Intel is one of SISO's system integrator partners and Intel invested in SISO in 2000. \\
\hline Nokia & Nokia is an affiliated member of Intel Communications Alliance. \\
\hline Fujitsu & $\begin{array}{l}\text { Fujitsu collaborated with Intel in its strategic shift from UNIX/SPARC structure to Linux/Intel structure in its mission-critical } \\
\text { enterprise server (2003). }\end{array}$ \\
\hline Alcatel & Alcatle and Intel cooperated to improve time to market of AdvancedTCA platforms for mobile service providers (2005). \\
\hline Cisco & $\begin{array}{l}\text { Cisco and Intel has been collaborating in a variety of areas, such as gigabit networking, enterprise network security, wireless and } \\
\text { mobile. }\end{array}$ \\
\hline Ericsson & $\begin{array}{l}\text { Ericsson partnered with Intel deploy services and applications on mobile PCs that are powered by Ericsson's mobile broadband } \\
\text { and IMS solutions and Intel Mobile technology (2006). }\end{array}$ \\
\hline NEC & $\begin{array}{l}\text { NEC Solutions (America) partnered with IBM and Intel to deliver a new 64-bit computing solution. NEC's Express5800/1000 } \\
\text { enterprise server is based on Intel Itanium } 2 \text { and IBM DB2 Universal Database software (2004). }\end{array}$ \\
\hline Hitachi & Hitachi is a customer of Intel; its blade server is based on 64bit Intel Itanium 2 processor (1.66GHz). \\
\hline NTT & $\begin{array}{l}\text { DoCoMo, Intel and IBM collaborated to introduce Trusted Mobile Platform specification to enhance mobile device security } \\
\text { (2004). }\end{array}$ \\
\hline
\end{tabular}


Figure 2: Intel's network of relationships

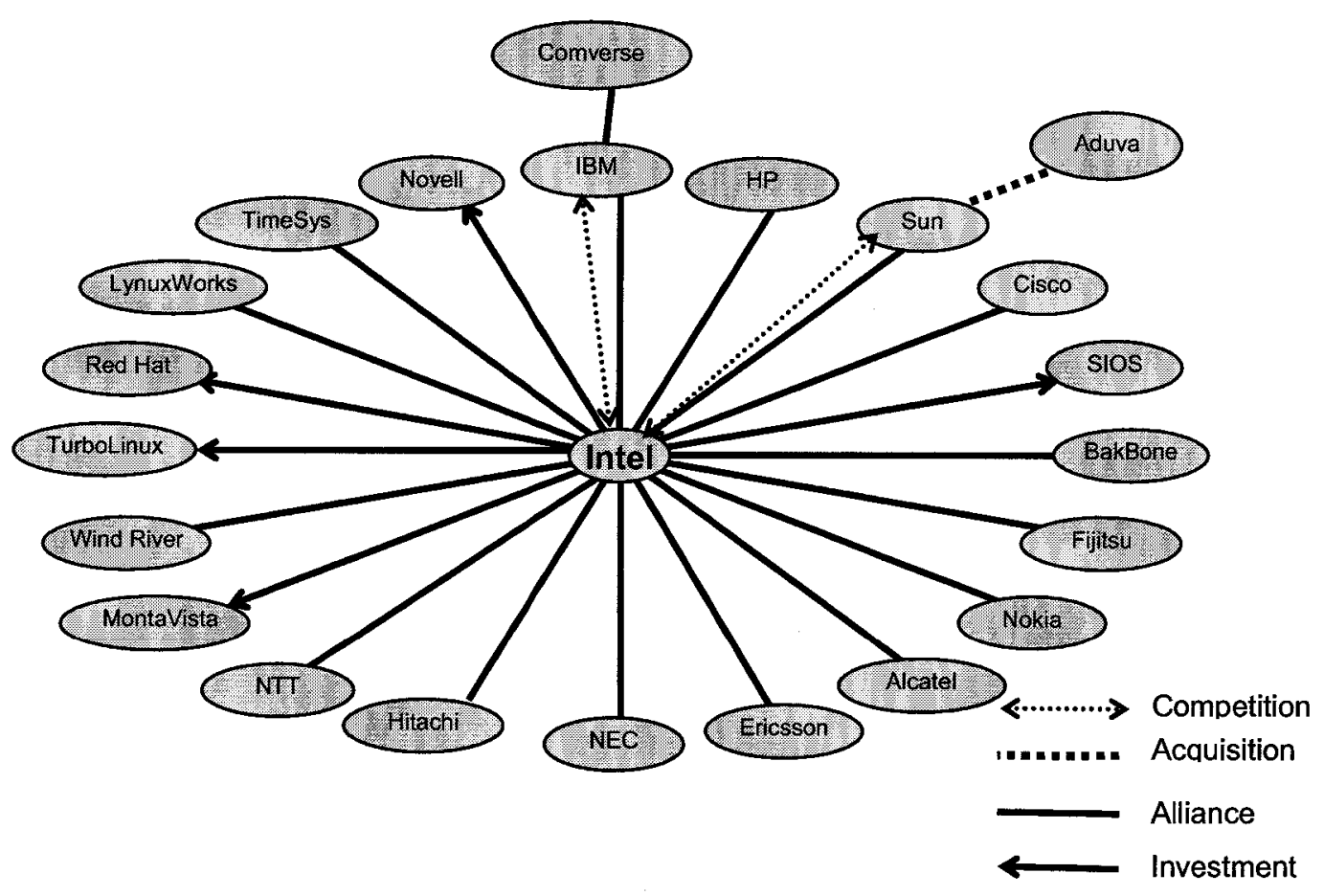




\section{Appendix G2: Sun's network of relationships}

Sun established partnership with its competitors (Intel, HP, IBM, Red Hat, Novell, TurboLinux, MontaVista, Novell and Wind River), supplier (Intel), customers (NTT, NEC, Alcatel, Nokia, Hitachi, Ericsson and Fujitsu) and complementors (BakBone, SISO and

Comverse). Sun also invested in TimeSys and LynuxWorks and acquired Aduva.

\begin{tabular}{|c|c|}
\hline Intel & $\begin{array}{l}\text { Sun competes with Intel in chip market. } \\
\text { Intel and Sun formed a strategic alliance to promote Solaris Operating System and Intel Xeon processors (2007). }\end{array}$ \\
\hline $\mathrm{HP}$ & $\begin{array}{l}\text { Sun is competing with HP in server market. } \\
\text { HP and Sun cooperated on HP StorageAuthority technology and Sun StorEdge Enterprise Storage Manager Advanced } \\
\text { Applications. }\end{array}$ \\
\hline IBM & $\begin{array}{l}\text { Sun is competing with IBM in server market. } \\
\text { IBM and Sun formed alliance to support IBM Information Management Solutions for the Sun Solaris platform. }\end{array}$ \\
\hline MontaVista & MontaVista's Linux is available in Sun's Netra CT900 ATCA Blade Servers. \\
\hline Novell/SuSE & Novell/SuSE's Enterprise Linux was chosen by Sun as operating system of choices in its x64 servers and workstations. \\
\hline TurboLinux & TurboLinux joined Sun's StarOffice NOW program in 2000. \\
\hline Wind River & Wind River and Sun cooperated on porting Carrier Grade Linux stack to Sun's UltraSPARC T1 (2006). \\
\hline LynuxWorks & LynuxWorks received investment from Sun Venture Capital Partners in 2000. \\
\hline TimeSys & TimeSys got equity financing from Sun in 2002. \\
\hline Red Hat & Sun competes with Red Hat in operating system. \\
\hline
\end{tabular}




\begin{tabular}{|c|c|}
\hline & $\begin{array}{l}\text { Red Hat and Sun established a global alliance agreement to distribute Red Hat's Enterprise Linux operating system and Sun's } \\
\text { Java Virtual Machine (2003). }\end{array}$ \\
\hline BackBone & $\begin{array}{l}\text { Sun is one of BakBone's strategic partners and they reached a strategic technology licensing and distribution agreement with Sun } \\
(2006) .\end{array}$ \\
\hline Comverse & $\begin{array}{l}\text { Sun is one of Comverse's infrastructure partners, and they announced an agreement of an effort bringing Internet applications to a } \\
\text { broad range of global telecom companies (2000). }\end{array}$ \\
\hline SISO(10art-ni) & Sun is business partner of SIOS (10 Art-ni ). \\
\hline Nokia & $\begin{array}{l}\text { Ericsson, Nokia and Sun cooperated to form the Telecommunications Platform Initiative aiming to unite the Network Equipment } \\
\text { Provider (NEP) community and assist telecommunications operators and service providers (2006). }\end{array}$ \\
\hline Fujitsu & $\begin{array}{l}\text { Fujitsu and Sun expanded their } 20 \text {-year strategic relationship to include the joint development and delivery of Solaris and } \\
\text { SPARC-based systems. The two companies also announced the plan to merge their Sparc processor-based server lines (2004). }\end{array}$ \\
\hline Alcatel & $\begin{array}{l}\text { Alcatel and Sun signed a major cooperation agreement to improve the cost-effectiveness of Alcatel's existing IT-based mobile } \\
\text { core network solutions (2005). }\end{array}$ \\
\hline Ericsson & $\begin{array}{l}\text { Ericsson, Nokia and Sun cooperated to form the Telecommunications Platform Initiative aiming to unite the Network Equipment } \\
\text { Provider (NEP) community and assist telecommunications operators and service providers (2006). }\end{array}$ \\
\hline NEC & $\begin{array}{l}\text { NEC and Sun has been cooperating on delivering advanced high performance computing (HPC) solutions integrating Sun Fire } \\
\text { servers (2006). }\end{array}$ \\
\hline Hitachi & $\begin{array}{l}\text { Hitachi and Sun extended their alliance in high-end storage systems, which lets Sun resell data center-class storage systems } \\
\text { designed by Hitachi Data Systems (2003). }\end{array}$ \\
\hline NTT & $\begin{array}{l}\text { NTT COMWARE implemented its next-generation SIP application server on Sun's Netra ATCA blade running carrier-grade } \\
\text { Solaris Operating System (2005). Sun Microsystems K.K. and NTT DATA concluded an agreement to cooperate in thin client } \\
\text { solutions, which combines NTT DATA's GO-Global with the Sun's Sun Ray Ultra-Thin Client. }\end{array}$ \\
\hline Aduva & Aduva was acquired by Sun in 2006 . \\
\hline
\end{tabular}


Figure 3: Sun's network of relationships

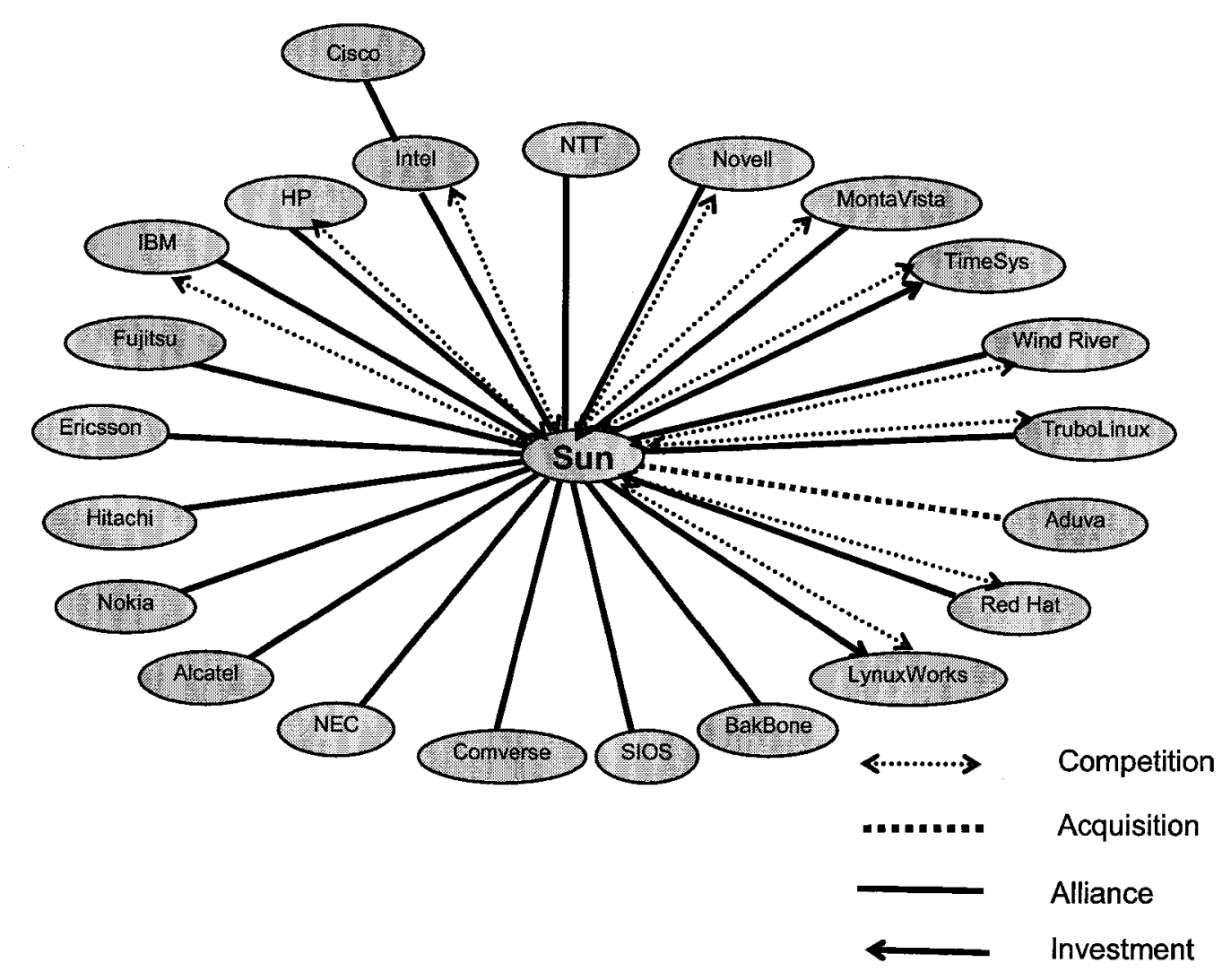




\section{Appendix G3: HP's network of relationships}

HP established partnerships with its competitors (IBM and Sun), customers (NTT, Ericsson, Hitachi, Nokia, Alcatel, NEC, and Cisco), suppliers (Intel) and complemntors (Novell, Red Hat, TurboLinux, LynuxWorks, Comverse and BakBone). HP also invested in complementor- SISO.

\begin{tabular}{|c|c|}
\hline Intel & $\mathrm{HP}$ is among the first members of the Intel Communications Alliance. \\
\hline Sun & $\begin{array}{l}\text { Sun competes with HP in server market. } \\
\text { Sun and HP established a storage management software OEM and joint development relationship for HP StorageAuthority } \\
\text { technology and Sun StorEdge Enterprise Storage Manager Advanced Applications. }\end{array}$ \\
\hline IBM & $\begin{array}{l}\text { IBM competes with HP in server market. } \\
\text { IBM and HP cooperated in IBM/HP DB2 Information Management Alliance to offer solutions for the corporate Business } \\
\text { Intelligence marketplace. }\end{array}$ \\
\hline Novell/SuSE & HP is one of Novell's Alliance Partners, and HP worked with Novell/SuSE to develop SuSE's CGL. \\
\hline TurboLinux & $\mathrm{HP}$ is a strategic partner of TurboLinux. \\
\hline LynuxWorks & Lynuxworks worked with HP to provide LynuxOS for HP's mid-Range and high-End LaserJet Printers \\
\hline Red Hat & $\begin{array}{l}\text { Red Hat has a strong partnership with HP. Red Hat Linux is the operating system chosen by HP server and workstation } \\
\text { platforms including x86 32- and 64-bit, ProLiant and Integrity server lines. }\end{array}$ \\
\hline BackBone & HP is a strategic partner of BakBone. \\
\hline Comverse & $\begin{array}{l}\text { HP is one of the partners of Comverse, a provider of software and systems that enable multimedia network based enhanced } \\
\text { services. }\end{array}$ \\
\hline
\end{tabular}




\begin{tabular}{|l|l|}
\hline & \\
\hline SISO(10art-ni) & $\begin{array}{l}\text { SIOS (10Art-Ni) develops and markets systems for Linux and Java-based software and hardware products. HP is one of the } \\
\text { investors of SISO. }\end{array}$ \\
\hline Nokia & Nokia worked with HP to provide wireless print solution for its cell phone (2003). \\
\hline Alcatel & Lucent-Alcatel partnered with HP and Microsoft to deliver Triple-Play IPTV (2006). \\
\hline Ericsson & Ericsson outsourced its global IT and computing services to HP (2003). \\
\hline NEC & $\begin{array}{l}\text { NEC and HP signed a memorandum of understanding to form an alliance and joint ventures to provide outsourcing services to } \\
\text { enterprise customers (2002). }\end{array}$ \\
\hline Hitachi & $\begin{array}{l}\text { Hitachi and HP formed joint technology agreement and original equipment manufacturer agreement relationship on high-end } \\
\text { storage solutions (2001). }\end{array}$ \\
\hline NTT & $\begin{array}{l}\text { NTT Facilities and HP Japan formed a business alliance to introduce large-scale information-processing systems such as blade } \\
\text { servers, facility construction including power supply and air conditioning systems, facility assessment consulting and system } \\
\text { integration and maintenance. }\end{array}$ \\
\hline Cicso & $\begin{array}{l}\text { Cisco and HP formed strategic alliance combine Cisco's IP networking solutions, with HP's telecommunications management } \\
\text { solutions. HP is Cisco's Global Support Partner (highest level of Cisco certification). }\end{array}$ \\
\hline
\end{tabular}


Figure 4: HP's network of relationships

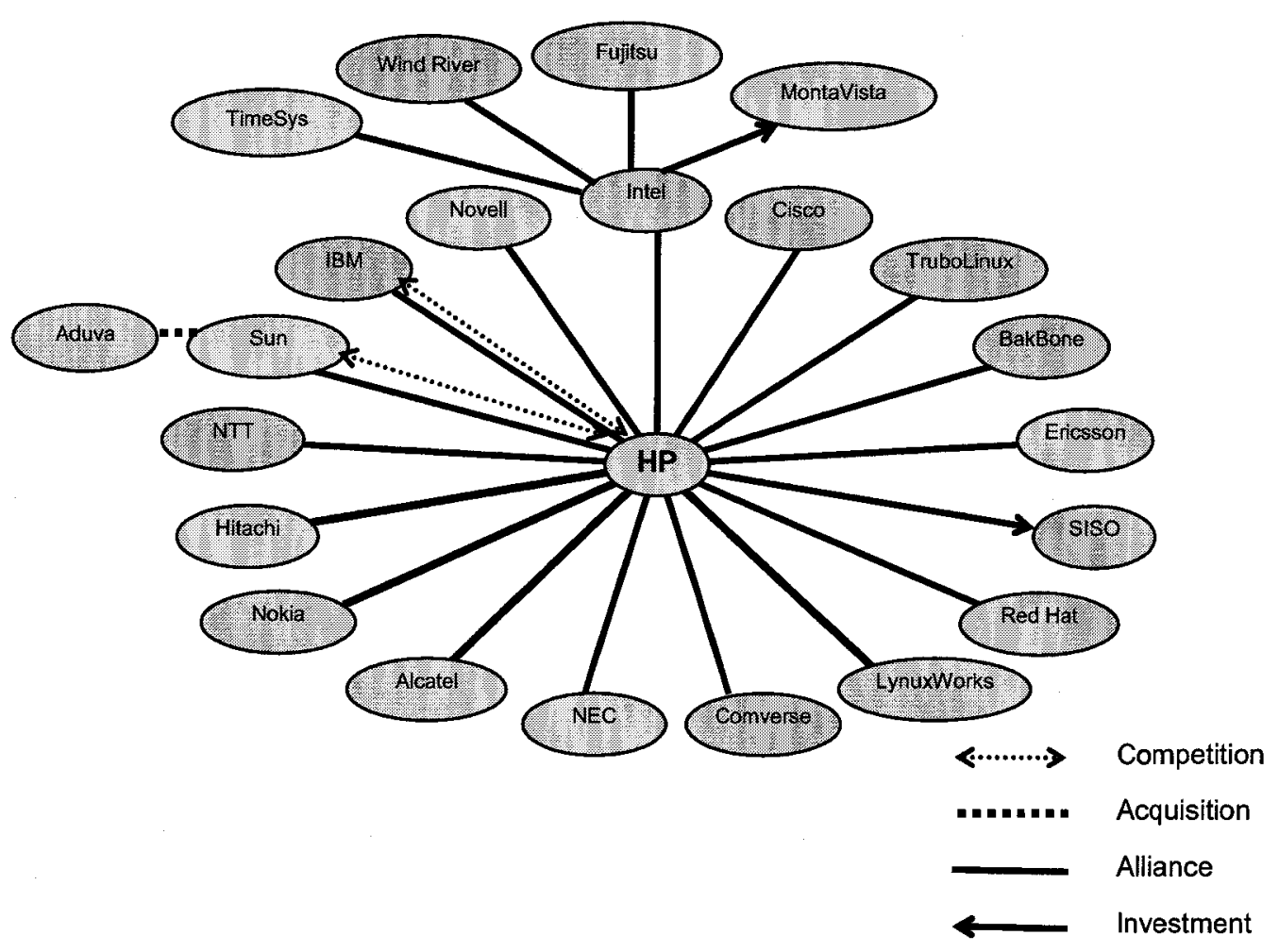




\section{Appendix G4: IBM's network of relationships}

IBM established partnerships with all the companies including its competitors (Sun and HP), customers (NTT, NEC, Ericsson,

Hitachi, Nokia, Alcatel, Fujitsu and Cisco), suppliers (Intel) and complemntors (Novell, TimeSys, Red Hat, Wind River,

TurboLinux, LynuxWorks, Aduva, SISO, Comverse and BakBone). IBM also financially related to Linux distributor MontaVista.

\begin{tabular}{|c|c|}
\hline Intel & Intel worked with IBM to provide Linux Telecom solutions based on blade server technology (2003). \\
\hline Sun & $\begin{array}{l}\text { Sun competes with IBM with in server market. } \\
\text { Sun and IBM work closely on IBM Information Management Solutions for the Sun Solaris platform. Their cooperation includes } \\
\text { joint engineering and product development, coordinated service and support, recruitment of strategic business partners, } \\
\text { cooperative marketing and sales. }\end{array}$ \\
\hline HP & $\begin{array}{l}\text { HP competes with IBM with in server market. } \\
\text { IBM and HP cooperated in IBM/HP DB2 Information Management Alliance to offer solutions for the corporate Business } \\
\text { Intelligence marketplace. }\end{array}$ \\
\hline Novell/SuSE & $\begin{array}{l}\text { Novell is a member of IBM's Strategic Alliance program -- IBM's highest tier partner status. And IBM is one of Novell's } \\
\text { Alliance Partners }\end{array}$ \\
\hline TurboLinux & IBM is one of the partners of TurboLinux. \\
\hline Wind River & IBM is one of the partners of Wind River. \\
\hline LynuxWorks & IBM is a member company in LynuxWorks' SynergyWorks Alliance. \\
\hline Red Hat & Red Hat has a strong partnership with HP. Red Hat Linux is the operating system chosen by HP server and workstatio \\
\hline
\end{tabular}




\begin{tabular}{|c|c|}
\hline & including x86 32- and 64-bit, ProLiant and Integrity server lines. \\
\hline Timesys & $\begin{array}{l}\text { TimeSys signed a technical agreement with IBM to deliver TimeSys Linux RTOS and TimeSys' Linux- and Windows-hosted } \\
\text { development tools on IBM's PowerPC } 440 \text { family of System-on-a-Chip embedded processors (2003). }\end{array}$ \\
\hline Red Hat & $\begin{array}{l}\text { Red Hat has been elevated to IBM's Strategic Alliance program and formed joint marketing pact with IBM to provide Linux- } \\
\text { based support and services to the enterprise sector. }\end{array}$ \\
\hline BackBone & IBM is one of BakBone's strategic partners. \\
\hline Comverse & IBM is one of Comverse's business partners. \\
\hline SISO(10art-ni) & IBM is one of SIOS's system integrator partners. \\
\hline Nokia & $\begin{array}{l}\text { Nokia and IBM cooperated on wireless products and services built on IBM's Wireless Enterprise Delivery Environment and } \\
\text { WebSphere infrastructure and Nokia's mobile phones and devices. IBM developed its WebSphere Everyplace Access client for } \\
\text { Nokia's Symbian operating system (2003). }\end{array}$ \\
\hline Alcatel & Lucent-Alcatel involved in pilot programs to test the IBM Carrier Grade Open Framework Reference Implementation (2004). \\
\hline Ericsson & $\begin{array}{l}\text { Ericsson and IBM reached an agreement to link the global IBM Developer Center for Telecom and e-business (DCTe) with the } \\
\text { worldwide network of Ericsson Mobility World Centers to help enable ISVs to test their applications that connect to telephone } \\
\text { networks (2002). }\end{array}$ \\
\hline NEC & $\begin{array}{l}\text { NEC Solutions (America), Inc., a premier provider of integrated solutions for the Connected Enterprise in North America, } \\
\text { partnered with IBM and Intel to deliver a new 64-bit computing solution (2004). }\end{array}$ \\
\hline Fujistu & $\begin{array}{l}\text { Fujistu and IBM agreed to achieve interoperability between IBM's WebSphere Telecom Application Server and Fujitsu's } \\
\text { GeoServe server and collaborate on autonomic computing standards (2002). }\end{array}$ \\
\hline Hitachi & $\begin{array}{l}\text { Hitachi made agreement with IBM to support IBM's mirroring and replication software; they also collaborate on product } \\
\text { interoperability testing to support compatibility between Hitachi's storage systems and IBM's zSeries mainframe (2005). }\end{array}$ \\
\hline NTT & NTT DoCoMo, Intel and IBM collaborated on Trusted Mobile Platform Specification (2004). \\
\hline Cicso & Cisco is a Premier IBM Business Partner. IBM is a Cisco Global Certified Partner and IBM is one of only two Cisco partners that \\
\hline
\end{tabular}




\begin{tabular}{|l|l|}
\hline & hold the Cisco Global Certification status. \\
\hline Aduva & $\begin{array}{l}\text { Aduva (acquired by SUN in 2006), the company providing Linux management solutions, is one of the member of IBM's } \\
\text { PatnerWorld and a winner of the "Hot Linux Solution" award in the annual IBM PartnerWorld Beacon Awards competition. }\end{array}$ \\
\hline
\end{tabular}


Figure 5: IBM's network of relationships

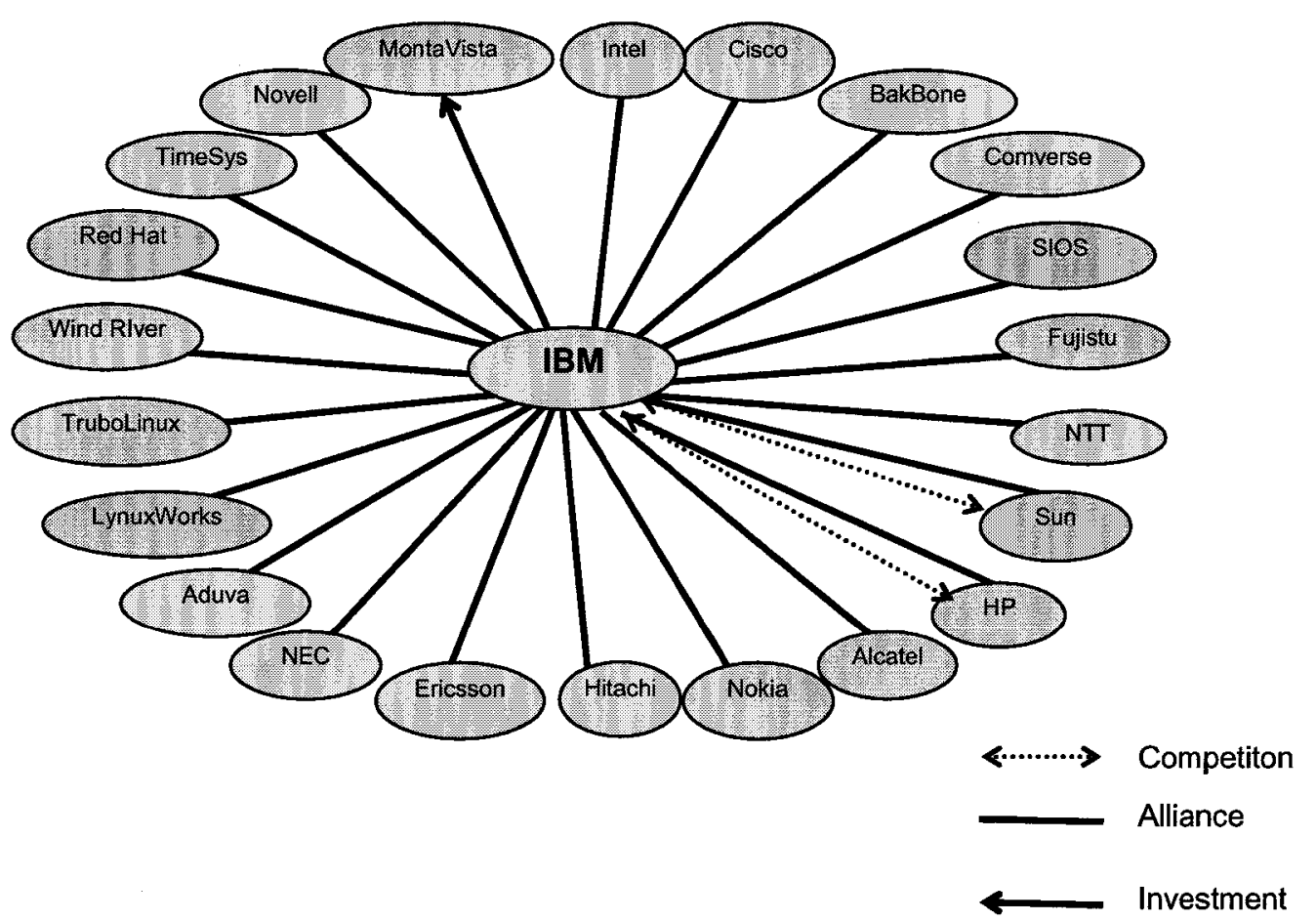




\section{Appendix G5: MontaVista's network of relationships}

MontaVista established partnerships with its competitor (Sun) and customers (Ericsson, Alcatel, Nokia and Hitachi). MontaVista received investment from its customers (NTT) and complementors (Intel and IBM).

\begin{tabular}{|c|c|}
\hline Intel & Intel is a strategic partner with MontaVista and took an equity stake in MontaVista in 2000. \\
\hline Sun & Sun uses MontaVista CGE operating system on its ATCA Blades. \\
\hline IBM & $\begin{array}{l}\text { IBM has strategic relationship with MontaVista and worked with MontaVista Software to certify CGE } 3.0 \text { on IBM } \\
\text { BladeCenter servers. } \\
\text { IBM is one of the investors of MontaVista. }\end{array}$ \\
\hline Novell/SuSE & Competitor \\
\hline TurboLinux & Competitor \\
\hline Wind River & Competitor \\
\hline MontaVista & Competitor \\
\hline LynuxWorks & Competitor \\
\hline Red Hat & Competitor \\
\hline Timesys & Competitor \\
\hline Red Hat & Competitor \\
\hline Nokia & $\begin{array}{l}\text { Nokia uses MontaVista's Linux on networking equipment for carrying both voice and data traffic using the Internet's } \\
\text { communication standard. }\end{array}$ \\
\hline
\end{tabular}




\begin{tabular}{|l|l|}
\hline Alcatel & $\begin{array}{l}\text { Lucent-Alcatel worked with MontaVista to provide open platform enabling powerful fixed, mobile and converged end-user } \\
\text { centric applications. Alcatel signed a major multi-year corporate contract with MontaVista Software for CGE, making it a key } \\
\text { building block for Alcatel products with embedded or real-time constraints (2003). }\end{array}$ \\
\hline Ericsson & $\begin{array}{l}\text { Ericsson signed up as MontaVista's business partner and bought several subscriptions allowing the use of MontaVista's } \\
\text { programming tools (2001). }\end{array}$ \\
\hline NEC & $\begin{array}{l}\text { NEC joined MontaVista's hardware vendor self-certification program and resells MontaVista Linux in Japan (2004). } \\
\text { MontaVista and NEC have made a "long-term collaboration" deal under to optimize commercial Linux distributions for } \\
\text { various NEC hardware reference designs (2004). }\end{array}$ \\
\hline Hitachi & Hitachi established strategic alliance with MontaVista. \\
\hline NTT & NTT DoCoMo, Inc. invested \$3 million in newly issued preferred stock for an equity stake in MontaVista in 2004. \\
\hline
\end{tabular}


Figure 6: MontaVista's network of relationships

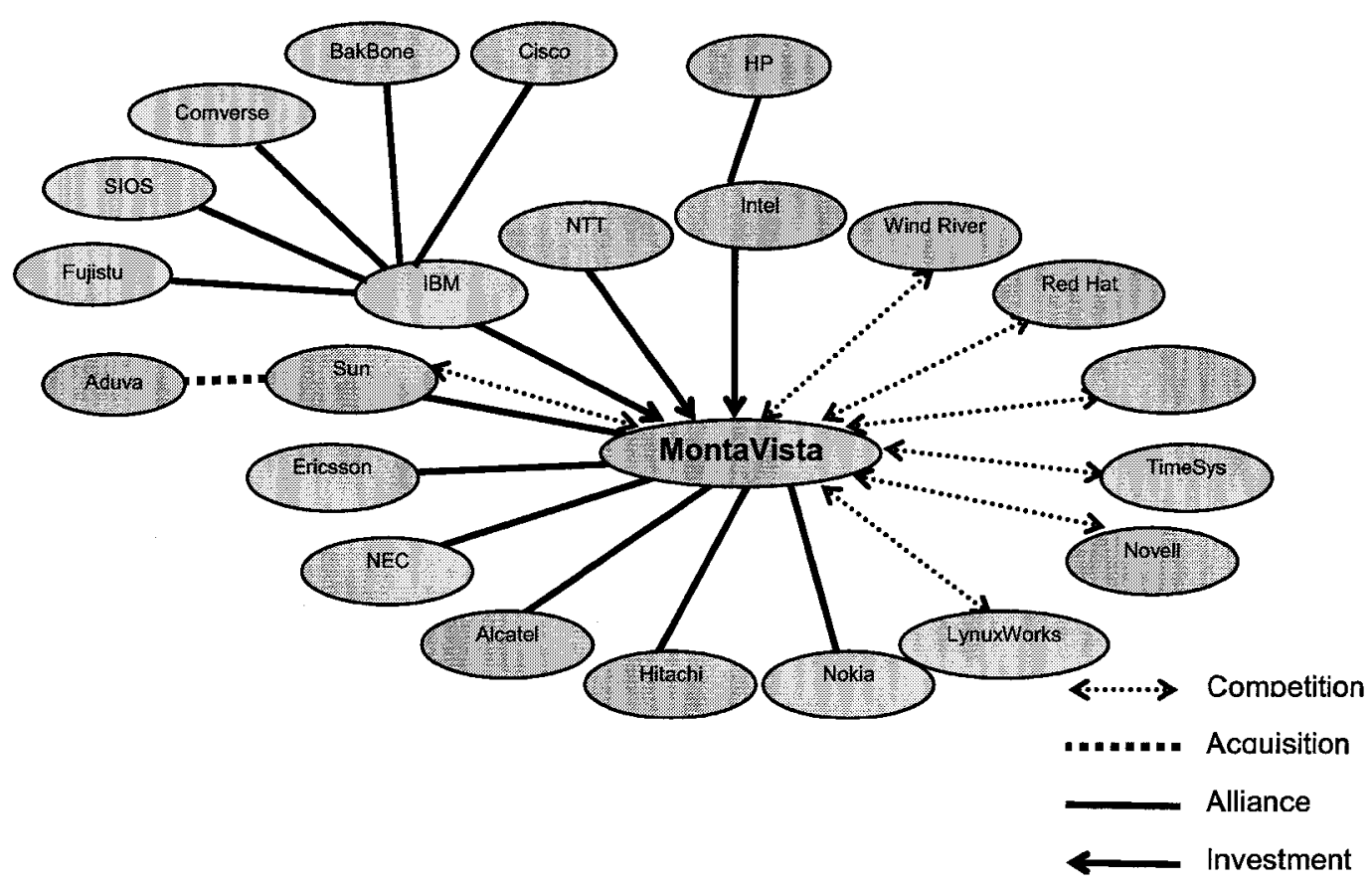




\section{Appendix G6: Wind River's network of relationships}

Wind River established partnerships with its competitors (Red Hat, Sun), customers (Ericsson, NEC, Alcatel, Fujitsu and Hitachi) and complemntors (IBM and Intel).

\begin{tabular}{|l|l|}
\hline Intel & $\begin{array}{l}\text { Intel is Wind River' strategic partner; and Wind River is an affiliated member of Intel Communications Alliance. Wind } \\
\text { River's Workbench On-Chip Debugging tool provides multi-core on-chip debugging solution for the Intel IOP342 processor } \\
(2006) .\end{array}$ \\
\hline Sun & $\begin{array}{l}\text { Sun and Wind River are working on the combination of Sun's UltraSPARC T1 processor, the industry's first multi-threaded } \\
\text { open source chip architecture, and Wind River Platform for Network Equipment, Linux Edition (2006). }\end{array}$ \\
\hline IBM & IBM is one of the strategic partners of Wind River. \\
\hline Novell/SuSE & Competitor \\
\hline TurboLinux & Competitor \\
\hline MontaVista & Competitor \\
\hline LynuxWorks & Competitor \\
\hline MontaVista & Competitor \\
\hline Timesys & Competitor \\
\hline Red Hat & $\begin{array}{l}\text { Red Hat and Wind River announced their partnership to develop a Linux-based embedded software platform. The partnership } \\
\text { aimed to pair Wind River's leadership in the embedded market with Red Hat's presence in the open-source world (2004). }\end{array}$ \\
\hline
\end{tabular}




\begin{tabular}{|l|l|}
\hline Alcatel & Alcatel is one of the telecom equipment customers of Wind River Platform. \\
\hline Ericsson & $\begin{array}{l}\text { Ericsson and Intel cooperated with Wind River on TIPC protocol, which provides portability of code between Linux and } \\
\text { VxWorks operating system. }\end{array}$ \\
\hline NEC & NEC is one of Wind River's platform partners. \\
\hline Fujistu & Fujitsu is one of Wind River's community partners. \\
\hline Hitachi & $\begin{array}{l}\text { Hitachi and Wind River collaborated in their Center of Excellence program, which combines engineering and marketing } \\
\text { resources of the two companies to facilitate porting, optimization and distribution of Wind River's embedded software for } \\
\text { Hitachi processors (2001). }\end{array}$ \\
\hline
\end{tabular}




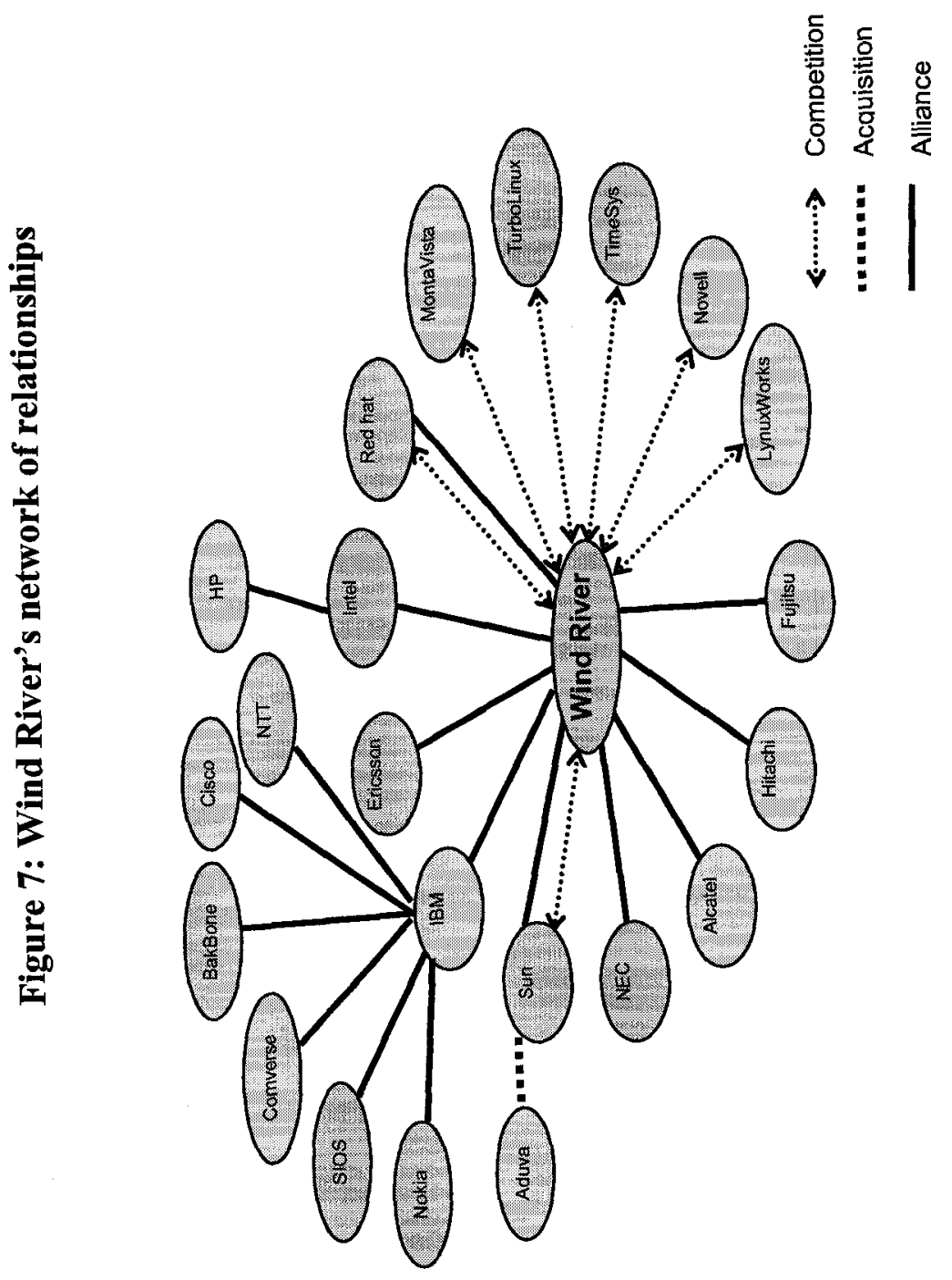




\section{Appendix G7: Red Hat's network of relationships}

Wind River established partnerships with its competitors (Red Hat, Sun), customers (Ericsson, NEC, Alcatel, Fujitsu and Hitachi) and complemntors (IBM and Intel).

\begin{tabular}{|l|l|}
\hline Intel & Intel and Red Hat created a global program to provide Linux solutions for its customers. Intel invested in Red Hat in 1998. \\
\hline Sun & $\begin{array}{l}\text { Sun and Red Hat established a global alliance to distribute Red Hat's Enterprise Linux operating system and Sun's Java } \\
\text { Virtual Machine (2003). }\end{array}$ \\
\hline HP & $\begin{array}{l}\text { IBM is one of the OEM Premier Partners of Red Hat. IBM and Red Hat created a program to boost Linux-based solutions } \\
\text { among independent software vendors (2005). IBM also pre-installed Red Hat Enterprise Linux in its xSeries servers. }\end{array}$ \\
\hline Novell/SuSE & $\begin{array}{l}\text { HP is one of the OEM Premier Partners of Red Hat. Red Hat Linux is running on HP server and workstation platforms across } \\
\text { the x86 32- and 64-bit, ProLiant and Integrity server lines. }\end{array}$ \\
\hline TurboLinux & Competitor \\
\hline Wind River & $\begin{array}{l}\text { Wind River and Red Hat collaborated on developing Linux-based embedded software platform (2004). } \\
\text { Competitor }\end{array}$ \\
\hline MontaVista & Competitor \\
\hline LynuxWorks & Competitor \\
\hline Timesys & Competitor \\
\hline SISO(10art-ni) & $\begin{array}{l}\text { SISO (10 Art-ni) and Red hat expanded their business partnership in 2004. Under the agreement, SISO integrates and } \\
\text { delivers Red Hat Enterprise Linux and Red Hat Application Server. }\end{array}$ \\
\hline
\end{tabular}




\begin{tabular}{|l|l|}
\hline Nokia & $\begin{array}{l}\text { Nokia selected Red Hat Linux for its Network Business Group as the primary OS for its carrier-grade server platforms } \\
(2006) .\end{array}$ \\
\hline Ericsson & $\begin{array}{l}\text { Ericsson and Red Hat made an agreement in 2000. According the agreement, Red Hat would provide specialized Linux } \\
\text { operating system in Ericsson's Internet enabled home devices. }\end{array}$ \\
\hline NEC & NEC is Red Hat's OEM Premier Partner. \\
\hline Fujistu & $\begin{array}{l}\text { Fujitsu is one of the OEM Premier Partners of Red Hat. They signed a global partnership agreement in 2003 to collaborate in } \\
\text { software development, marketing, system configuration, sales, delivery, and support efforts to optimize Red Hat Enterprise } \\
\text { Linux for use in Fujitsu hardware. Fujitsu PRIMEQUEST Intel Architecture servers are running Red Hat enterprise Linux } \\
(2005) .\end{array}$ \\
\hline Hitachi & $\begin{array}{l}\text { Hitachi is one of the OEM Premier Partners of Red Hat. Hitachi launched BladeSymphony blade server running Red Hat } \\
\text { Enterprise Linux (2005). }\end{array}$ \\
\hline NTT & NTT is Red Hat's customer. Red Hat provides in-house Linux training to employees at NTT (2002). \\
\hline
\end{tabular}


Figure 8: Wind River's network of relationships

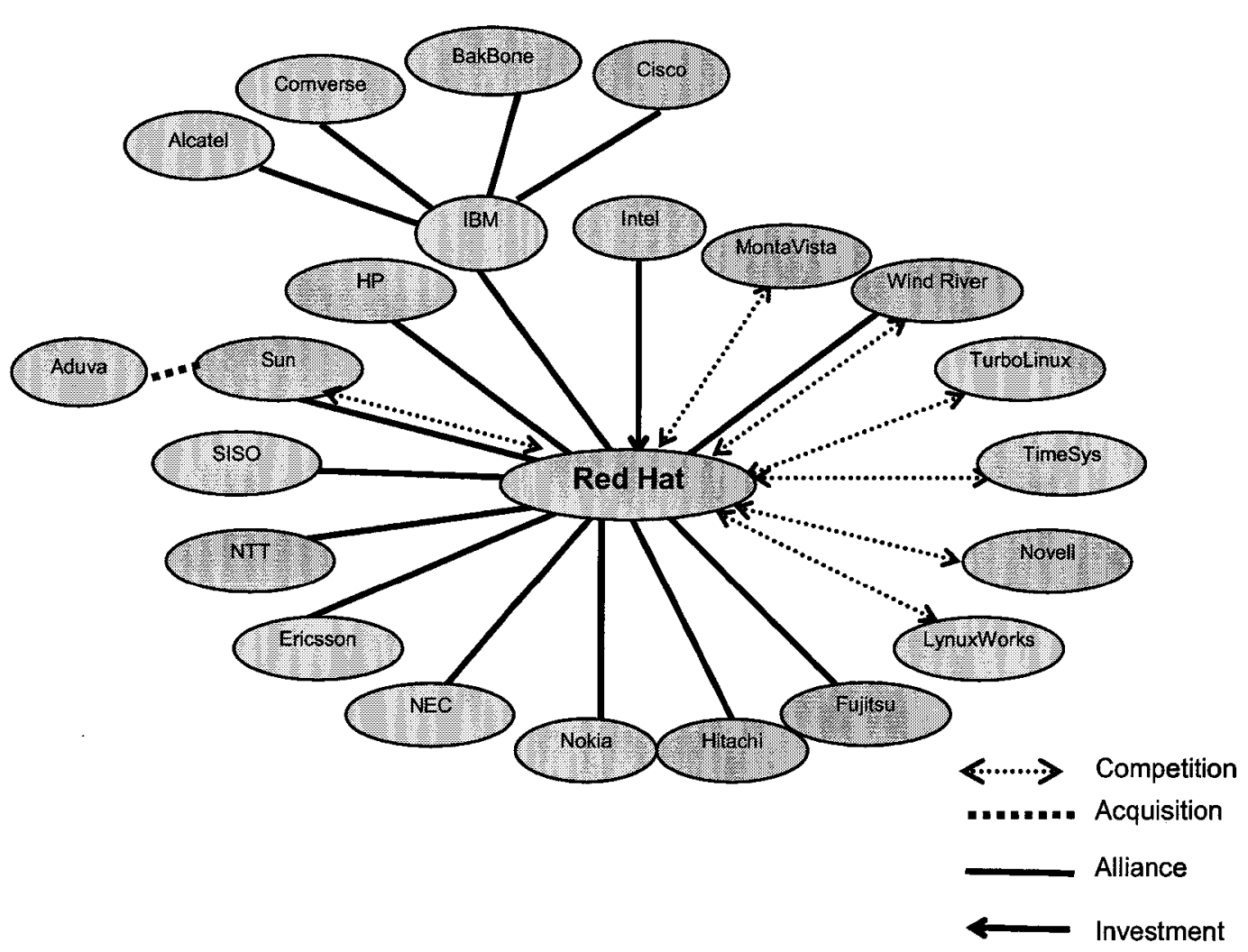




\section{Appendix G8: Ericsson's network of relationships}

Ericsson established partnerships with its competitors (Nokia, NEC, and Cisco), customer (NTT) and suppliers (IBM, Intel, HP, Sun, Fujitsu, Hitachi, MontaVista, Wind River and Red Hat).

\begin{tabular}{|c|c|}
\hline Intel & $\begin{array}{l}\text { Intel partnered with Ericsson to speed-up the deployment of services and applications on mobile PCs that are powered by } \\
\text { Ericsson's mobile broadband and IMS solutions and sport Intel Core Micro-architecture. }\end{array}$ \\
\hline & $\begin{array}{l}\text { IBM and Ericsson reached an agreement to link the global IBM Developer Center for Telecom and e-business (DCTe) with the } \\
\text { worldwide network of Ericsson Mobility World Centers to help enable ISVs to test their applications that connect to telephone } \\
\text { networks (2002). Ericsson signed an agreement to outsource the development, implementation and maintenance of information } \\
\text { technology applications supporting the handset maker's business and operations worldwide (2003). }\end{array}$ \\
\hline Sun & $\begin{array}{l}\text { Nokia and Ericsson teamed up with Sun Microsystems to create an alliance, Telecommunications Platform Initiative (TPI), to } \\
\text { assist telecoms operators and service providers in finding the right solutions for their network requirements and encouraging a } \\
\text { common platform infrastructure (2006). Nokia, Ericsson and Siemens are jointly defining specifications for an open standard to } \\
\text { speed the adoption of direct-call push to talk service over GPRS (2003). }\end{array}$ \\
\hline HP & Ericsson signed a five-year outsourcing contract of global IT and on-demand computing services with HP in 2003. \\
\hline Wind River & $\begin{array}{l}\text { Wind River cooperated with Ericsson on TIPC protocol, which provides portability of code between Linux and Wind River's } \\
\text { VxWorks operating system. }\end{array}$ \\
\hline MontaVista & MontaVista signed up Ericsson as major new business partners. \\
\hline Red Hat & $\begin{array}{l}\text { Red Hat and Ericsson announced a strategic initiative to jointly develop consumer products and services for home } \\
\text { communications. Ericsson pays Red Hat to create specialized versions of the Linux operating system in several Internet-enabled } \\
\text { devices for the home. Red Hat will help Ericsson adapt its product line to Linux, and both companies will engage in joint } \\
\text { marketing and branding work (2000). }\end{array}$ \\
\hline
\end{tabular}


Figure 9: Ericsson's network of relationships

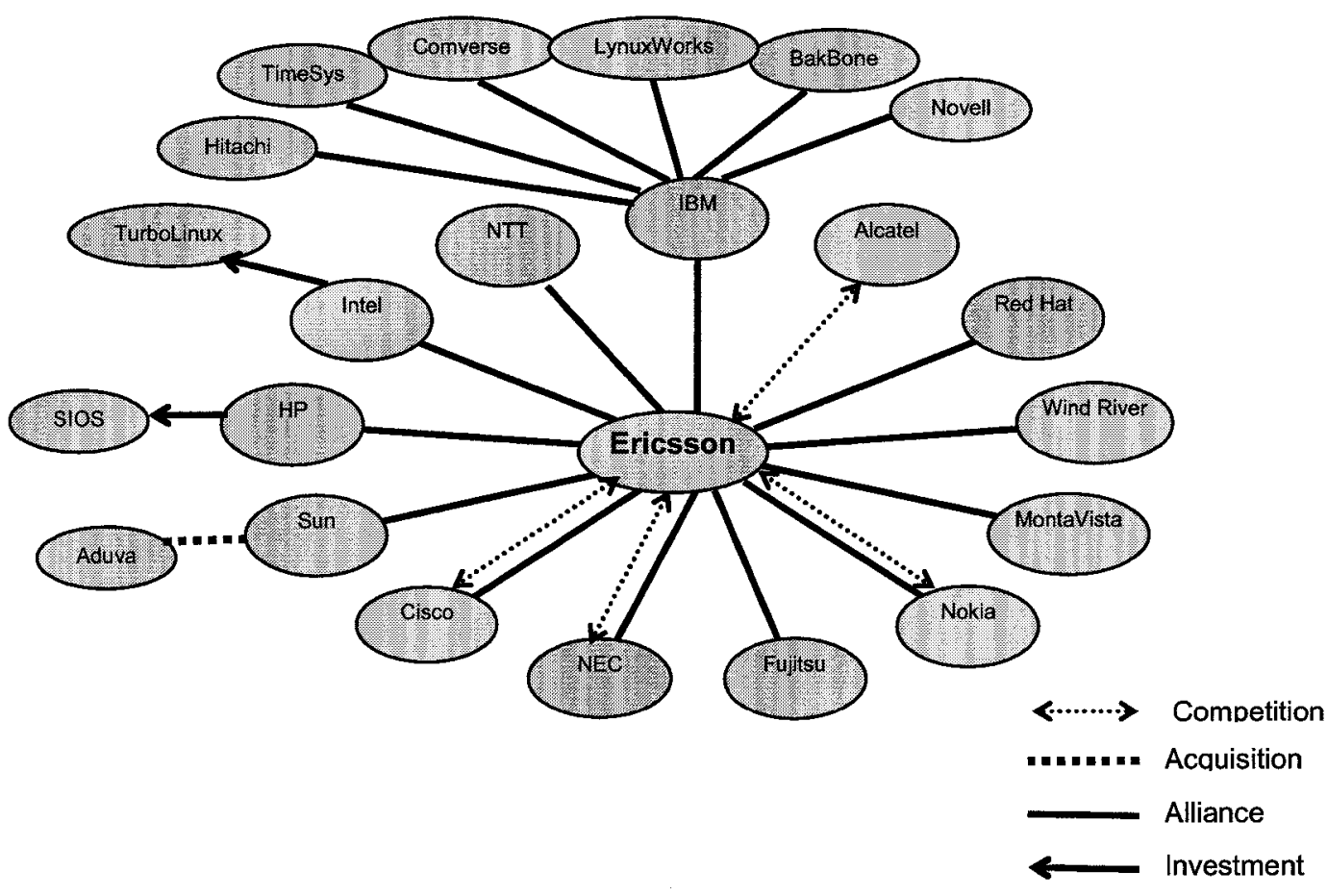




\section{Appendix G9: NTT's network of relationships}

NTT established partnerships with its suppliers (IBM, Intel, HP, Sun, Fujitsu, Hitachi, Alcatel, Nokia, NEC, Ericsson, Cisco and

Red Hat) and complementors (Comverse). NTT also invested in its suppliers (MontaVista and TurboLinux)

\begin{tabular}{|l|l|}
\hline Intel & $\begin{array}{l}\text { NTT DoCoMo, Intel and IBM collaborated to introduce Trusted Mobile Platform specification to enhance mobile device } \\
\text { security. }\end{array}$ \\
\hline IBM & $\begin{array}{l}\text { NTT DoCoMo, Intel and IBM collaborated to introduce Trusted Mobile Platform specification to enhance mobile device } \\
\text { security. }\end{array}$ \\
\hline HP & $\begin{array}{l}\text { NTT Facilities and HP Japan formed a business alliance to introduce large-scale information-processing systems such as } \\
\text { blade servers, facility construction including power supply and air conditioning systems, facility assessment consulting and } \\
\text { system integration and maintenance. }\end{array}$ \\
\hline MontaVista & $\begin{array}{l}\text { Sun Microsystems K.K. and NTT DATA concluded an agreement to cooperate in thin client solutions, which combines NTT } \\
\text { DATA's GO-Global with the Sun's Sun Ray Ultra-Thin Client. }\end{array}$ \\
\hline Nokia & $\begin{array}{l}\text { NTT DoCoMo and Nokia launched a joint action plan to accelerate the development based on the open mobile architecture } \\
\text { initiative. NTT DoCoMo and Nokia cooperated in promoting open mobile architecture for WCDMA-based 3G services } \\
\text { (2001). }\end{array}$ \\
\hline Alcatel & $\begin{array}{l}\text { Lucent-Alcatel announced a partnership with NTT Advanced Technology Corp. to offer Alcatel's high-speed Internet access } \\
\text { products through NTT's sales channels in Japan. }\end{array}$ \\
\hline Ericsson & $\begin{array}{l}\text { NTT DoCoMo, Fujitsu, Mitsubishi, Renesas , Sharp and Sony Ericsson Mobile Communications today announced that they } \\
\text { plan to jointly develop a next-generation mobile phone platform for dual-mode handsets supporting HSDPA2/W-CDMA (3G) } \\
\text { and GSM/GPRS/EDGE (2G) technologies (2007). }\end{array}$ \\
\hline
\end{tabular}




\begin{tabular}{|l|l|}
\hline NEC & $\begin{array}{l}\text { Motorola, NEC, NTT DoCoMo, Panasonic Mobile Communications, Samsung Electronics, and Vodafone announced their } \\
\text { intent to establish the world's first global, open Linux-based software platform for mobile devices (2006). NTT DoCoMo } \\
\text { works with NEC and MontaVista Carrier Grade Linux for operation with its network (2003). }\end{array}$ \\
\hline Fujistu & $\begin{array}{l}\text { NTT DoCoMo, Fujitsu, Mitsubishi, Renesas, Sharp and Sony Ericsson Mobile Communications today announced that they } \\
\text { plan to jointly develop a next-generation mobile phone platform for dual-mode handsets supporting HSDPA2/W-CDMA (3G) } \\
\text { and GSM/GPRS/EDGE (2G) technologies (2007). }\end{array}$ \\
\hline Hitachi & $\begin{array}{l}\text { NTT, Hitachi and Matsushita reached an agreement to begin joint research targeting the development of "HIKARI Commerce } \\
\text { Services"- next-generation E-commerce services (2002). }\end{array}$ \\
\hline Comverse & $\begin{array}{l}\text { Comverse, a supplier of software and systems enabling network-based multimedia enhanced communication services, } \\
\text { announced a licensing partnership agreement with NTT DoCoMo to advance marketing of the Comverse i-mode (2004). }\end{array}$ \\
\hline
\end{tabular}




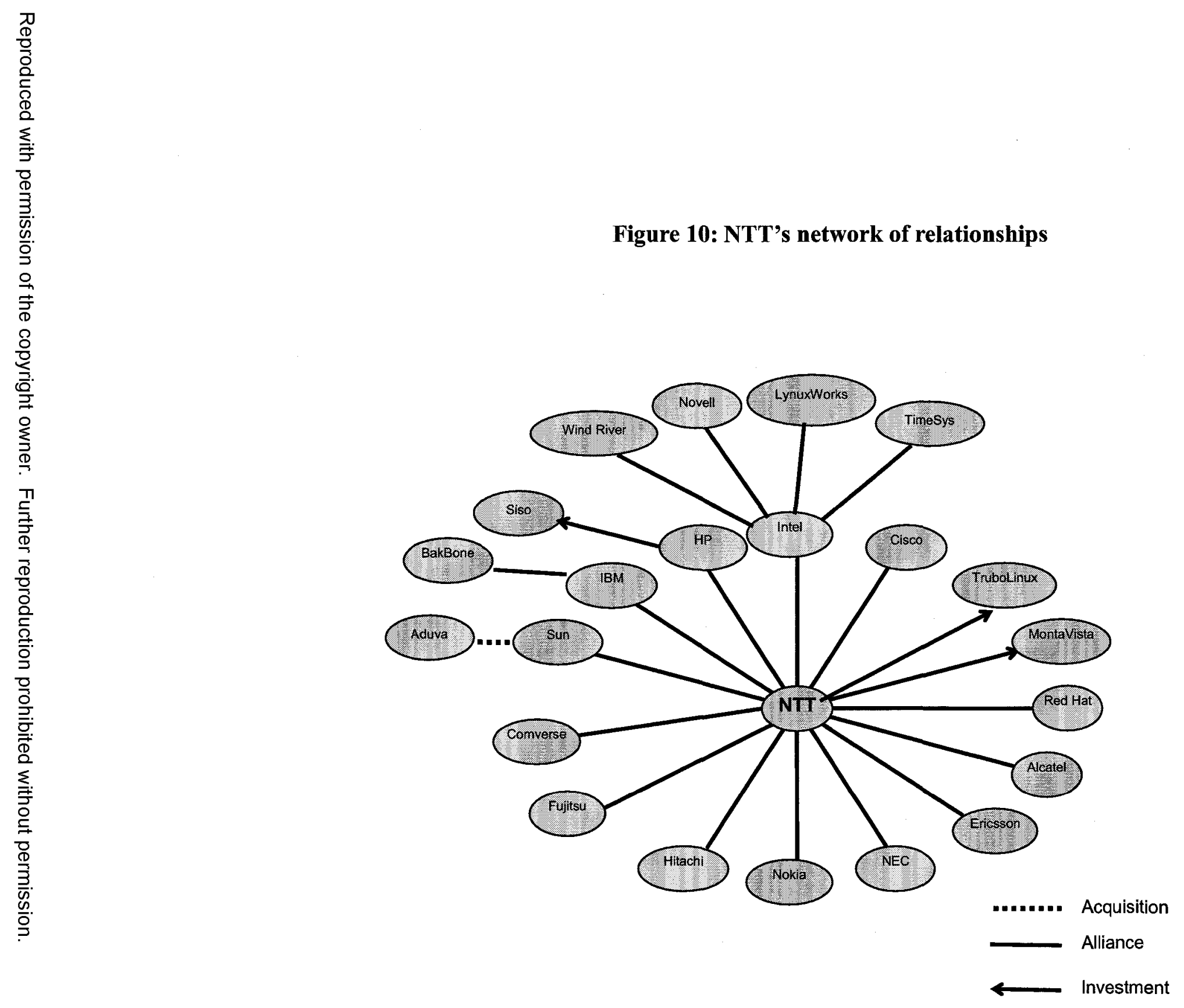




\section{Appendix H: Keystone strategies}

\begin{tabular}{|c|c|c|c|c|c|c|c|c|c|}
\hline Keystone criteria & Intel & Sun & HP & IBM & $\begin{array}{c}\text { Monta- } \\
\text { Vista }\end{array}$ & $\begin{array}{l}\text { Wind } \\
\text { River }\end{array}$ & Red Hat & Ericsson & NTT \\
\hline $\begin{array}{l}1 . \\
\text { Company's degree of links } \\
\text { was ranked in top } 4\end{array}$ & $20(3)$ & $21(2)$ & $17(4)$ & $22(1)$ & & & & & \\
\hline $\begin{array}{l}\text { 2.A } \\
\text { Developed a platform on } \\
\text { which other companies } \\
\text { can developed their } \\
\text { products }\end{array}$ & & & $\begin{array}{l}\text { Create } \\
\text { Debian, a } \\
\text { free CGL } \\
\text { distribution } \\
\text { that benefit } \\
\text { the } \\
\text { community }\end{array}$ & $\begin{array}{l}\text { Open } \\
\text { Integrated } \\
\text { Platform for } \\
\text { Telecom, a } \\
\text { program in } \\
\text { which it will } \\
\text { test third- } \\
\text { party } \\
\text { software for } \\
\text { carrier } \\
\text { operations } \\
\text { on a } \\
\text { platform that } \\
\text { consists of } \\
\text { Intel-based } \\
\text { IBM servers, } \\
\text { carrier-grade } \\
\text { Linux and } \\
\text { IBM } \\
\text { middleware. }\end{array}$ & & & & & \\
\hline $\begin{array}{l}\text { 2.B } \\
\text { Provided solutions to } \\
\text { benefit the ecosystem }\end{array}$ & $\begin{array}{l}\text { Deliver } \\
\text { interoperable } \\
\text { components } \\
\text { and building } \\
\text { blocks based } \\
\text { on CGL and } \\
\text { Intel } \\
\text { platform. }\end{array}$ & & & & & & & & \\
\hline & & & & & & & & & \\
\hline
\end{tabular}




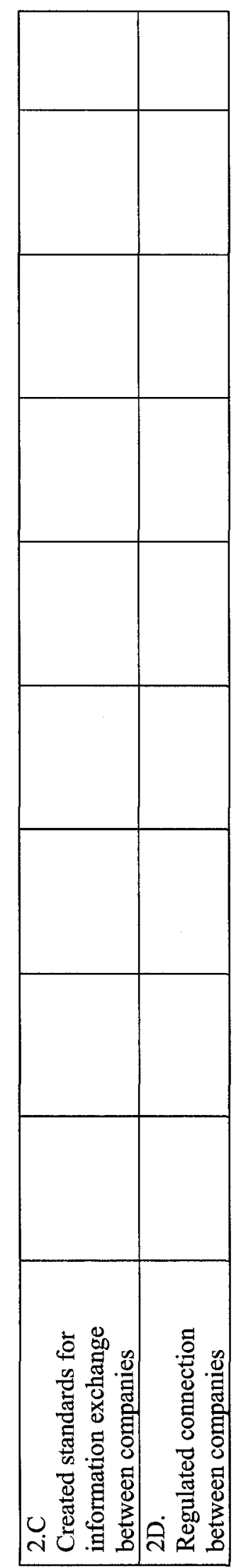


Appendix I: Dominator strategies

\begin{tabular}{|c|c|c|c|c|c|c|c|c|c|}
\hline Dominator criteria & Intel & Sun & HP & IBM & $\begin{array}{c}\text { Monta } \\
\text { Vista }\end{array}$ & $\begin{array}{l}\text { Wind } \\
\text { River }\end{array}$ & $\begin{array}{l}\text { Red } \\
\text { Hat }\end{array}$ & Ericsson & NTT \\
\hline $\begin{array}{l}1 . \\
\text { Company's degree of links } \\
\text { was ranked in top } 4\end{array}$ & $20(3)$ & $21(2)$ & $17(4)$ & $22(1)$ & & & & & \\
\hline $\begin{array}{l}2 . \\
\text { Company developed } \\
\text { vertically integrated CGL } \\
\text { products on its own }\end{array}$ & & & & & & & & & \\
\hline $\begin{array}{l}3 . \\
\text { Two or more employees sit } \\
\text { as officers of CGL Working } \\
\text { Group } \\
\text { (data accessed from CGL } \\
\text { website on August 7,2007) }\end{array}$ & $\begin{array}{l}\text { Technical } \\
\text { Subcommittee } \\
\text { Chair: } \\
\text { Terence } \\
\text { Chen, Intel } \\
\text { (1) }\end{array}$ & & & $\begin{array}{l}\text { Steering } \\
\text { Committee } \\
\text { Chair: Peter } \\
\text { R. } \\
\text { Badovinatz, } \\
\text { IBM } \\
\text { (1) }\end{array}$ & $\begin{array}{l}\text { 1.Marketing } \\
\text { Subcommittee } \\
\text { Chair: Robert } \\
\text { Monkman, } \\
\text { Montavista } \\
\text { Specifications } \\
\text { Subcommittee } \\
\text { Chair: Steve } \\
\text { Dake, } \\
\text { Montavista } \\
\text { (2) }\end{array}$ & & & & $\begin{array}{l}\text { Develop } \\
\text { ment } \\
\text { Subcom } \\
\text { mittee } \\
\text { Chair: } \\
\text { Takashi } \\
\text { Ikebe, } \\
\text { NTT } \\
\text { Network } \\
\text { Service } \\
\text { Systems } \\
\text { Laborato } \\
\text { ries } \\
\text { (1) } \\
\end{array}$ \\
\hline
\end{tabular}

